OECD SME and Entrepreneurship Papers No. 17

Workplace organisation and innovation in small and medium-sized

Edward Lorenz, enterprises

\section{Jonathan Potter}

https://dx.doi.org/10.1787/11732c0c-en 
OECD SME and Entrepreneurship Papers

\title{
Workplace Organisation and Innovation in Small and Medium-Sized Enterprises
}

\author{
Edward Lorenz and Jonathan Potter
}

\begin{abstract}
This paper examines the relationship between workplace organisation and innovation in small and medium-sized enterprises (SMEs). It uses data for 30 countries, drawn from the European Company Survey, the OECD Programme for International Assessment of Adult Competencies and the Community Innovation Survey. It contrasts SMEs adopting a "learning organisation" or "discretionary learning" form of workplace organisation with SMEs adopting more hierarchical organisational forms. Learning organisation or discretionary learning SMEs are characterised by high levels of self-planning of tasks by employees, teamwork, knowledge exchange with employees and supervisors, on-the-job training, and employee performance incentives. They account for approximately onethird of SMEs across the countries examined. SMEs with this form of work organisation are more likely than other SMEs to develop new products/services and processes. At a macro level, countries with high proportions of these SMEs have higher rates of new-tothe-market innovations among SMEs and of SME innovation collaborations with other firms and organisations. The findings point to the potential role of policies favouring organisational change in SMEs as a means of stimulating SME innovation.
\end{abstract}

JEL codes: J24, L23, L53, O32, O33

Keywords: SMEs, Innovation, Skills, Workplace Organisation

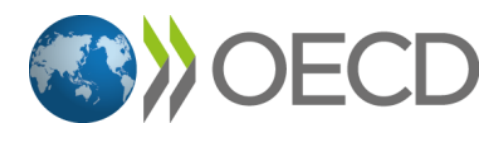




\section{ABOUT THE OECD}

The OECD is a multi-disciplinary inter-governmental organisation of 36 member countries which engages in its work an increasing number of non-members from all regions of the world. The Organisation's core mission today is to help governments work together towards a stronger, cleaner, fairer global economy. Through its network of 250 specialised committees and working groups, the OECD provides a setting where governments compare policy experiences, seek answers to common problems, identify good practice, and coordinate domestic and international policies. More information available: www.oecd.org.

\section{ABOUT THE SME AND ENTREPRENEURSHIP PAPERS}

The series provides comparative evidence and analysis on SME and entrepreneurship performance and trends and on a broad range of policy areas, including SME financing, innovation, productivity, skills, internationalisation, and others.

\section{DISCLAIMERS}

This paper is published under the responsibility of the Secretary-General of the Organisation for Economic Co-operation and Development (OECD). The opinions expressed and the arguments employed herein do not necessarily reflect the official views of OECD member countries.

This paper was authorised for publication by Lamia Kamal Chaoui, Director, Centre for Entrepreneurship, SMEs, Regions and Cities, OECD.

This document and any map included herein are without prejudice to the status of or sovereignty over any territory, to the delimitation of international frontiers and boundaries and to the name of any territory, city or area.

Note by Turkey:

The information in this document with reference to "Cyprus" relates to the southern part of the Island. There is no single authority representing both Turkish and Greek Cypriot people on the Island. Turkey recognises the Turkish Republic of Northern Cyprus (TRNC). Until a lasting and equitable solution is found within the context of the United Nations, Turkey shall preserve its position concerning the "Cyprus issue".

Note by all the European Union Member States of the OECD and the European Union:

The Republic of Cyprus is recognised by all members of the United Nations with the exception of Turkey. The information in this document relates to the area under the effective control of the Government of the Republic of Cyprus.

\section{(C) OECD (2019)}

You can copy, download or print OECD content for your own use, and you can include excerpts from OECD publications, databases and multimedia products in your own documents, presentations, blogs, websites and teaching materials, provided that suitable acknowledgement of OECD as source and copyright owner is given. All requests for public or commercial use and translation rights should be submitted to rights@oecd.org. 


\section{Acknowledgements}

This paper was prepared by Professor Edward Lorenz, University of Nice-Sophia Antipolis and CNRS, France, and Dr. Jonathan Potter, Centre for Entrepreneurship, SMEs, Regions and Cities, OECD. It is based on research undertaken for the OECD's Working Party on SMEs and Entrepreneurship (WPSMEE). It benefitted from comments from the delegates of the WPSMEE. 


\section{Table of Contents}

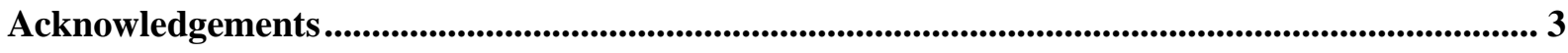

Executive Summary .......................................................................................................................................... 6

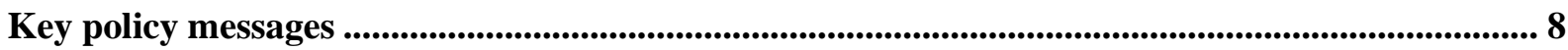

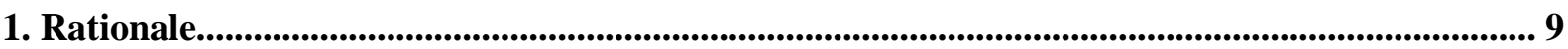

2. Methodology and data sources ......................................................................................................................... 11

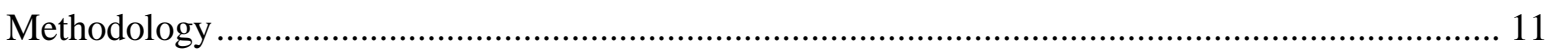

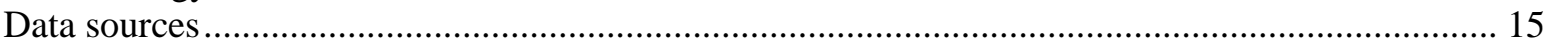

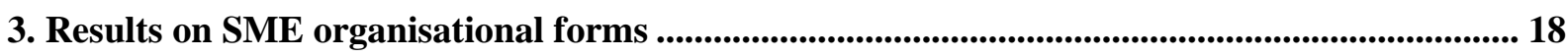

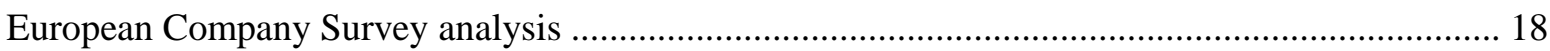

Programme for the International Assessment of Adult Competencies analysis ............................... 23

4. Results on relationships between SME organisational form and SME innovation .................... 29

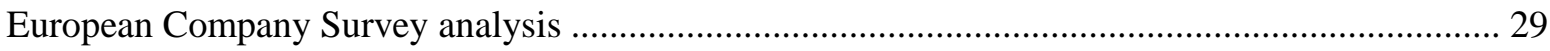

Programme for the International Assessment of Adult Competencies analysis ................................ 36

5. Conclusions and policy implications ..................................................................................................................... 40

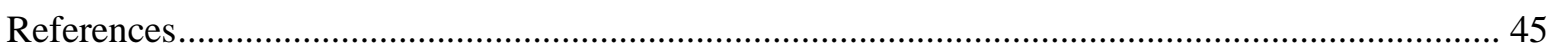

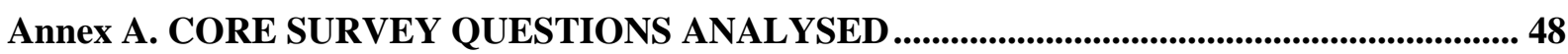

\section{Tables}

Table 2.1. Variables for the identification of SME organisational forms using ECS data for the EU

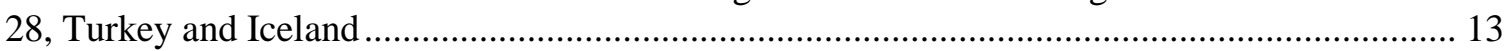

Table 2.2. Variables for the identification of SME organisational forms using PIAAC data for 23

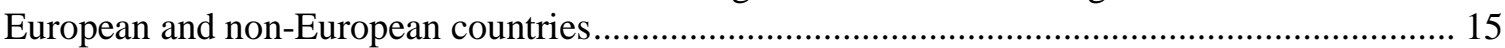

Table 3.1. Organisational forms in SMEs: EU-28, Turkey and Iceland (ECS data) ........................... 18

Table 3.2. Organisational forms by establishment size: EU-28, Turkey and Iceland (ECS data)......... 20

Table 3.3. Organisational forms by sector of activity: EU-28, Turkey and Iceland (ECS data) ........... 20

Table 3.4. National differences in SME organisational forms: EU-28, Turkey and Iceland (ECS

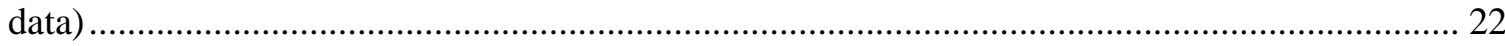

Table 3.5. Organisational forms in SMEs: 23 European and non-European countries (PIAAC data).. 23

Table 3.6. Forms of work organisation by establishment size, small establishments; 23 European

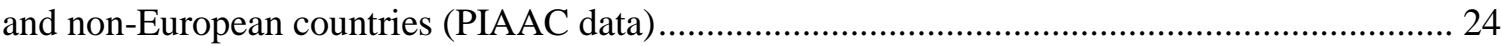

Table 3.7. Forms of work organisation in SMEs by sector of activity; 23 European and non-

European countries (PIAAC data). 
Table 3.8. Forms of work organisation in SMEs by occupational category: 23 European and nonEuropean countries

Table 3.9. Forms of work organisation in SMEs by education level: 23 European and non-European countries (PIAAC data)

Table 3.10. National differences in SME organisational forms: 23 European and non-European

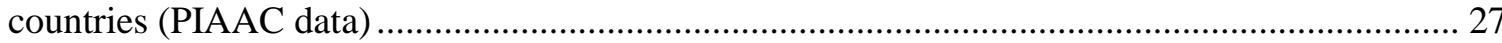

Table 4.1. Probit regression predicting product innovation outcomes from organisational form ......... 30

Table 4.2. Probit regression predicting process innovation outcomes from organisational form .......... 31

\section{Figures}

Figure 3.1. Correlation between adoption of the discretionary learning and learning organisation forms

Figure 4.1. Correlation between national share of learning organisation SMEs and national SME innovation rates

Figure 4.2. Correlation between national share of HRM hybrid SMEs and national SME innovation rates

Figure 4.3. Correlation between national share of simple organisation SMEs and national SME innovation rates

Figure 4.4. Correlation between national share of discretionary learning SMEs and national SME

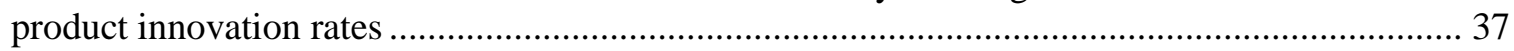

Figure 4.5. Correlation between national share of constrained learning SMEs and national SME

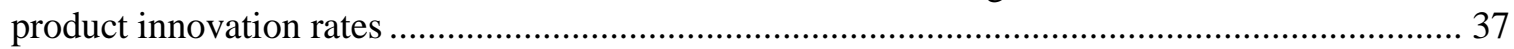

Figure 4.6. Correlation between national share of simple SMEs and national SME product innovation rates

\section{Boxes}

Box 2.1. The Third European Company Survey

Box 2.2. The OECD Programme for the International Assessment of Adult Competencies (PIAAC)

Survey

Box 5.1. The Finnish Workplace Development Programme (TYKE and TYKES) ............................. 41

Box 5.2. Swedish Programmes for Workplace Innovation .................................................................. 43 


\section{Executive Summary}

How firms organise their work practices can influence their innovation levels through better utilisation of employee competences and initiative

Recent academic research shows that investment in research and development (R\&D) and hiring of in-house R\&D workers tell only part of the story of how businesses innovate. The form of workplace organisation that firms adopt can be a further key influence on innovation. A firm's workplace organisation model can affect its ability to a) stimulate ideas in its workforce and transform them into innovation, and b) facilitate the absorption of knowledge from other firms and research organisations. While there is emerging evidence for these relationships in the business sector as a whole, little is known about the relationships between work organisation and innovation in small and medium-sized enterprises (SMEs) specifically.

Approximately one-third of SMEs adopt "learning organisation" or "discretionary learning" forms of work organisation, characterised by delegation of responsibilities to employees, team work and learning on the job

This study uses factor and cluster analysis to distinguish key types of SME organisational form using two different data sources. One set of data was drawn from the Third European Company Survey (ECS) administered in 2012 covering private establishments with between 10 and 249 employees in 30 European countries. Approximately one-third of the establishments can be classed as "learning organisation" SMEs. They are characterised by high levels of delegation of responsibility for the planning of tasks to employees, team working arrangements, on-the-job training, performance-related pay and appraisal, and regular staff meetings and interactions between employees and their supervisors. They differ from "simple organisation" SMEs, with low levels of employee discretion, training and involvement in firm innovation processes, and "hybrid human resources management (HRM)" SMEs, with a relatively hierarchical organisational design and average use of training and employee performance incentives.

A second set of data was drawn from Job Requirements Approach (JRA) module of the first wave of the OECD Programme for the International Assessment of Adult Competencies (PIAAC) undertaken in 2011-2012. This provides a sample of 32861 employees in private sector establishments with between 10 and 249 employees in 23 countries - Australia, Canada, Japan, Korea, the United States of America, Norway, 16 European Union countries and the Russian Federation. Three distinct classes of work organisation were identified: "discretionary learning", "constrained learning" and "simple" forms. Slightly more than one-third of SMEs can be classed as discretionary learning SMEs, operating with high employee discretion in planning work activities, high levels of learning and problem-solving, and high levels of information sharing. They correspond closely to the "learning organisation" SME form identified through the ECS analysis. 
Shares of learning organisation and discretionary learning SMEs are greater in Nordic countries

Learning organisation SMEs represent approximately $70 \%$ of SMEs in Sweden and Finland, and more than $40 \%$ in Denmark, Austria, Slovenia, Germany, Iceland, the Netherlands, and Ireland. However, they represent less than 25\% of SMEs in Croatia, the Slovak Republic, Turkey, the Czech Republic, Portugal, Bulgaria, Italy, Romania and Hungary.

The highest shares of employees working in discretionary learning SMEs are in Sweden and Finland, where they account for approximately $60 \%$ of employment. More than $50 \%$ of employees are in discretionary learning SMEs in Denmark, Austria, Belgium, the Czech Republic and Norway. The lowest shares are in Ireland, the Slovak Republic, the Russian Federation and Korea, which all have less than $30 \%$ of employees in discretionary learning SMEs.

There are relatively high shares of learning organisation and discretionary learning SMEs in knowledge-intensive business services and low shares in manufacturing, construction and transport. There is little difference in shares of learning organisation or discretionary learning modes by size of SME.

Learning organisation and discretionary learning SMEs innovate more and co-operate more for innovation

Firm-level econometric analysis using ECS data shows that learning organisation SMEs are more likely to develop new products, services and processes than hybrid HRM and simple organisation SMEs. Country-level correlation analysis using the ECS and PIAAC data and measures from the Community Innovation Survey 2012 show that higher shares of learning organisation SMEs and discretionary learning SMEs are correlated with higher shares of SMEs developing products and services that are new on national or world markets. They are also correlated with the share of SMEs that co-operate with other firms and organisations for the development of new products and processes.

The findings point to the relevance of policies that promote pro-innovation forms of workplace organisation for stimulating SME innovation

The results point to the potential for public policy to stimulate SME innovation by influencing workplace organisation arrangements in SMEs. Policies aiming to encourage employee discretion, teamwork and learning in SMEs can be expected to support SME innovation. This type of policy action can provide an important complement to traditional SME innovation policies based on stimulating R\&D activity. One policy avenue is offering business diagnostics, advice, consultancy, mentoring and leadership development to SME management. Another route involves financial and technical support for organisational change strategies in SMEs, as illustrated by initiatives such as the TYKE, TYKES and Liideri programmes in Finland and the Working Life Fund, Competent Workplace and Winning Services programmes in Sweden. A common approach is to award funding on a competitive basis to SMEs that propose to implement organisational change strategies in co-operation with outside experts. 


\section{Key policy messages}

- The forms of workplace organisation adopted by SMEs influence SME innovation levels.

- Forms of SME workplace organisation involving employee discretion and learning favour innovation.

- Features of SME workplace organisation involving employee discretion and learning associated with greater innovation in products, services and processes.

- This type of workplace organisation is also associated with greater co-operation with external actors for product and process development.

- Key features of such workplace organisation models are delegation of responsibility for the planning of tasks to employees, team working arrangements, on-the-job training, performance-related pay and appraisal, information sharing, and employee learning and problem-solving.

- This suggests a potential new type of policy aimed at stimulating SME innovation through influencing workplace organisation, complementing traditional measures stimulating $R \& D$ and innovation inputs.

- The need for more innovation-friendly forms of SME workplace organisation is strongest in countries with low shares of learning organisation and discretionary learning SMEs including Portugal, Bulgaria and Croatia.

- Scandinavian countries offer good examples of public programmes that support organisational change in SMEs, such as Liideri in Finland and the Competent Workplace and Winning Services programmes in Sweden.

- Business development services offering advice, consultancy and mentoring to SME management also have potential to encourage the introduction of more proinnovation work organisation models. 


\section{Rationale}

The role of workplace organisation in innovation has traditionally received only limited attention in innovation research and policy compared with R\&D activities. However, a growing body of research emerged during the last 15 years on the organisational dimension of innovation, including research streams on 'workplace innovation' (Erickson and Jacoby, 2003; Fricke and Totterdill, 2004; Kalmi and Kauhanen, 2008; Lorenz, 2013) and 'high involvement innovation' (El-Ella et al, 2013; Alasoini, et al. 2008; Hallgren, 2009). There is also growing policy interest in how workplace organisational structures impact on innovation in firms, as highlighted for example in the OECD's Innovation Strategy and work on innovative workplaces and skills (OECD, 2015; OECD, 2010).

One strand of the literature distinguishes between firms using a dominant sciencetechnology-innovation (STI) innovation mode with those using a dominant doing-usinginteracting (DUI) mode (Jensen et al., 2007; Fitjar and Rodríguez-Pose, 2012; Herstad and Brekke, 2012). The STI mode involves a systematic research-based search for global technological opportunities and scientific solutions to company problems. In contrast, the DUI mode involves processes of interactive learning among people internal and external to the enterprise for adopting existing knowledge and making progressive improvements of products and processes. It can be argued that workplace organisation is particularly important for innovation in firms working in the DUI mode. Whereas it is well known that SMEs are weak compared to large firms in their capacity to absorb new scientific and technical knowledge in the STI mode (suggesting a need for policy to stimulate R\&D activities in SMEs), relatively little is known about how organisational practices may affect SME innovation activities in the DUI mode (and the policy implications).

The workplace innovation and high involvement innovation literature distinguish between transformed or flexible organisations and more traditional or hierarchical ones (Ichniowski et al., 1997; Freeman and Lazear, 1995; Levine and Tyson, 1990; Lorenz et al., 2004, Osterman, 2000). Transformed/flexible organisations adopt managerial practices that enhance the firm's capacity for making incremental improvements to the efficiency of its work processes and the quality of its products and services. This includes practices designed to increase employee involvement in problem-solving and operational decisionmaking such as autonomous teams, problem-solving groups and employee responsibility for quality control. These firms also have an interest in adopting pay and promotion policies linking compensation and careers to individual, group or company performance. ${ }^{1}$

The distinction between hierarchical and transformed/flexible work systems can also be seen in Burns and Stalkers' (1961) classic distinction between 'bureaucratic' and 'organic' organisations. Mintzberg (1983) develops this into a more complex typology, identifying two types of organic organisation with a high capacity for adaptation - the 'operating adhocracy' and the 'simple organisation' - and two bureaucratic forms with a limited

1 This is based on the notion that employees will make greater efforts to improving the firm's capacity for learning and problem solving if they are promised a share of the quasi-rents deriving from their efforts. 
capacity for adaptation and innovation - the 'machine bureaucracy' and the 'professional bureaucracy'. ${ }^{2}$ The forms of work organisation and types of work practices that characterise these organisational forms are quite different. The simple organisation is rudimentary in terms of managerial hierarchies and relies on direct supervision by one individual (typically a manager). While work autonomy tends to be low in the simple organisation. By contrast, operating adhocracies rely on mutual adjustment in which employees coordinate their own work by means of horizontal communication within teams and across services. Various liaison devices such as project teams and task forces are used to facilitate the process of mutual adjustment. Work autonomy is high in the adhocracy. In contrast to these two forms, the machine bureaucracy has a high degree of centralisation, high task standardisation and limited employee discretion over how work is carried out. In the professional bureaucracy, centralisation is low and behaviour is regulated and standardised through the acquisition of standardised skills and the internalisation of professional norms and standards of conduct.

All these literatures identify a relationship between the types of managerial practices used in the firm and its ability to learn, adapt and innovate. However, whereas there has been significant examination of workplace organisational forms and innovation across firms and organisations in general, there has been little examination of the degree to which workplace organisation is an important influence on innovation in SMEs specifically. This paper aims to help close the gap in knowledge on the relationships between workplace organisation and innovation in SMEs and to explore the potential implications for policies aimed at SME innovation.

\footnotetext{
${ }^{2}$ Mintzberg also refers to a third bureaucratic form, the 'divisionalised' form. Unlike the other four configurations, he describes it as a partial structure superimposed on others (i.e. divisions) each of which is driven towards the machine bureaucracy.
} 


\section{Methodology and data sources}

\section{Methodology}

The paper analyses data from two complementary internationally-harmonised surveys offering information on workplace organisation forms; namely the Third European Company Survey (ECS) administered in 2012 and the Job Requirements Approach (JRA) module of the first wave of the OECD's Programme for the International Assessment of Adult Competencies (PIAAC) administered in 2011-2012. The paper makes use of the most recent data available from ECS.

The unit of enquiry for the ECS is the establishment. ${ }^{3}$ A senior manager responsible for personnel was interviewed in each establishment providing a range of data on workplace organisation and performance. The PIAAC JRA module is addressed to adults aged 16-65 years who are in employment to assess generic work skills requirements. The paper focuses on managers and employees in establishments with between 10 and 249 employees.

The two data sources are complementary because they have different country coverage (enabling the extension of findings to more countries), they emphasise different aspects of workplace organisation and learning arrangements and because they offer the views of both employers and employees. 4 The paper benefits from the fact that the two surveys were carried out at approximately the same point in time, allowing a 'triangulation' between different data sources which is unique and which makes conclusions regarding national rankings of forms of work organisation more robust.

To identify different SME organisational forms, the paper uses a method originally developed in Lorenz and Valeyre (2005) and extended in Arundel et al. (2007) and Holms et al. (2010). This method was also used in the examination of skills and innovative workplaces reported in OECD (2010). ${ }^{5}$ The approach applies factor and cluster analyses on

\footnotetext{
${ }^{3}$ The choice of the establishment rather than the company as the unit of enquiry in the ECS reflects the fact that most decisions relating to work organisation and task design are made by managers at the establishment level. The data in this paper therefore relate to small and medium sized establishments rather than to small and medium-sized enterprises (SMEs) per se. However, there is very strong overlap between these two groups. Only approximately $11 \%$ of establishments in the ECS sample are part of multi-plant firms with 250 employees or more. The vast majority of establishments are SMEs.

${ }^{4}$ In general, employees are in a better position than employers to provide a detailed characterisation of their tasks, the skills they use and the extent to which their work activity involves learning and problem-solving activity. Employers, on the other hand, are better placed to provide information on the overall structure of the establishment and the use of specific managerial practices affecting the division of tasks and responsibilities among employees (Greenan and Lorenz, 2013). For a discussion of complementary nature of employer and employee survey-based measures of organizational change and its economic and social impacts, see the Meadow Guidelines (Meadow Consortium, 2010)

${ }^{5}$ The method builds on the approach developed for OECD (2010), which examined conditions and trends in the period 1995-2010 in businesses in general using employee data from the European
} 
the basis of selected indicators of the establishment's organisational and human resource management (HRM) practices. ${ }^{6}$ The choice of indicators is based on two complementary literatures on the relation between organisational and HRM practices and firm innovation capacity. One is the 'high performance work places' literature (Applebaum et al. 2000; Becker and Gerhart, 1996; Becker and Huselid, 1998; Ichiniowski et al. 1997; Osterman, 1994, 2000; Ramsay et al., 2000). The other is the literature analysing the relation between organisational design and innovation (Burns and Stalker, 1961; Mintzberg, 1983; Lam, 2000).

Table 2.1 presents 11 binary variables constructed from the ECS in order to capture differences across SMEs in managerial practices and organisational designs. ${ }^{7}$ The total number of establishments in the sample is 21035 , covering the EU-28, Turkey and Iceland. The first five variables capture a number of practices that are characteristic of high performance workplaces including employee responsibility for the planning and execution of daily tasks, autonomous team organisation, task rotation, quality control practices and documenting good working practices as a basis for benchmarking. Other indicators capture employee involvement in the firm through the use of voluntary suggestion schemes and horizontal consultation in the firm through regular staff meetings and regular meetings between employees and their supervisors. Complementary human resources management policies are captured through indicators of on-the-job training, the use of performance pay and periodic performance appraisal.

Working Conditions Survey (EWCS). This paper extends that work by developing an SME specific analysis and by using different data sets resulting in novel clustering. Whereas OECD (2010) used employee data from EWCS, this paper combines ECS data for an employer-level analysis and a recent wave of PIAAC for an employee-level analysis. The use of these data sets allows for a comparison of national rankings of the adoption of different organisational forms from both the employee's and the employer's perspectives. This paper also adds the dimension of co-operation for innovation.

${ }^{6}$ For an overview of this research, see Chapter 2 of OECD (2010).

7 See Appendix 1 for the questions and coding used to construct the measures upon which the statistical analysis is based. List wise deletion of missing observations was applied on 10 of the 11 variables for which the percentage of missing values was less than 1 percent. In the case of the variable measuring on-the-job training for which 8 percent of the values were missing, Stata's 'impute' command for regression imputation was used to impute missing values. 
Table 2.1. Variables for the identification of SME organisational forms using ECS data for the EU 28, Turkey and Iceland

Weighted percentages

\begin{tabular}{ll}
\hline Variables & $\begin{array}{c}\% \text { of } \\
\text { establishments }\end{array}$ \\
\hline Work organisation & \\
\hline $\begin{array}{l}\text { Employee has or shares responsibility for planning and execution of daily } \\
\text { tasks }\end{array}$ & 44.4 \\
\hline Teamwork employees decide on division of tasks & 19.0 \\
\hline \multicolumn{2}{l}{ Task rotation $\quad$ employees do not decide on division of tasks } \\
\hline Employees document and record good work practices & 51.8 \\
\hline Establishment monitors quality & 66.3 \\
\hline Employee involvement and consultation & 60.3 \\
\hline Voluntary suggestion schemes & 74.1 \\
\hline Regular staff meetings open to all & 40.8 \\
\hline Regular meetings between employees and supervisor & 61.1 \\
\hline Training and incentives & 85.6 \\
\hline On the job training during last 12 months & 39.4 \\
\hline Individual or group performance pay & 48.5 \\
\hline Performance appraisal once a year* & 55.7 \\
\hline Number of observations & 21035 \\
\hline
\end{tabular}

* $40 \%$ or more of employees

Source: Third European Company Survey 2013, European Foundation for the Improvement of Living and Working Conditions.

A separate analysis is undertaken using the JRA module of the OECD PIAAC survey for employees in establishments with between 10 and 249 employees. The JRA module asks employees to indicate the level of skills that is required in their current work in several skill domains, including communication skills, the skills needed to work within teams, to work at multiple and flexible tasks, and to work more independently. ${ }^{8}$ This information is useful for examining the relationships suggested by the organisation design literature between the mechanisms used to coordinate work divided in different ways and such features of work organisation as the degree of job specialisation, the amount of learning and adaptation needed, and the extent to which employees exercise control over their work.

The organic kind of organisation that Mintzberg (1979) refers to as an adhocracy is characterised by the importance of employee involvement in the design of work activity as well as by employees' responsibility for planning and carrying out their work tasks. Three variables from PIAAC are used to capture these features of work organisation: control over

${ }^{8}$ See PIAAC Conceptual Framework of the Background Questionnaire Main Survey, OECD, November 2011. 
how the work is done or carried out; control over the sequence of tasks; and employee responsibility for planning work activities. Learning activities are described through three variables indicating whether or not the employee learns from the task performed and whether or not the employee is involved in complex and simple problem solving. The extent and nature of learning activity can be linked to the degree of standardisation of work and skills and the amount of discretion employees exercise over their work. Hierarchical forms of work organisation based on the standardisation of tasks will provide less scope for learning and creative use of one's own ideas. The degree of horizontal communication is captured by two variables: whether or not the employee shares information with coworkers; and whether or not the work involves co-operating with co-workers. The sharing of information with co-workers can be seen as an indicator of the soft forms of coordination Mintzberg (1979) refers to as 'mutual adjustment'.

For the purposes of this paper, 8 binary variables are derived from the data across three main dimensions: the cognitive dimension of learning and problem-solving activity; the extent of autonomy or discretion exercised by the employee in his or her daily work activity; and the extent of co-operation and knowledge exchange amongst employees within the organisation. Table 2.2 presents the frequencies of the 8 binary variables for the sample of 32861 employees working in private sector establishments with between 10 and 249 employees across the 23 OECD countries that participated in the first wave of PIAAC. ${ }^{9}$ A little over 43 percent of employees in the population are able to choose or change how they do their work and to choose or change the sequence of their tasks. A slightly larger share of employees plans their own work activities. Over 54 percent learn on the job from the tasks they perform. Complex problem-solving (37 percent of employees) is defined in terms of problems requiring at least 30 minutes to find a good solution whereas simple problem-solving (69 percent of employees) is defined as those requiring only 5 minutes. Some 62 percent of employees report sharing information with co-workers and 55 percent report co-operating in their job.

${ }^{9}$ The survey was undertaken in the US, Canada, Australia, the Russian Federation, Japan, Korea, Norway and the following 16 European countries: Austria, Belgium, Czech Republic, Denmark, Estonia, Finland, France, Germany, Ireland, Italy, Netherlands, Poland, Slovak Republic, Spain, and Sweden and the UK. 
Table 2.2. Variables for the identification of SME organisational forms using PIAAC data for 23 European and non-European countries

\begin{tabular}{|l|c|}
\hline Variables & \% of employees \\
\hline Discretion over how you do your work & 43.7 \\
Planning your own activities & 43.5 \\
Learning by doing from tasks performed & 54.9 \\
Complex problem-solving activity & 36.7 \\
Simple problem-solving activity & 68.7 \\
Sharing information with co-workers & 62.3 \\
Cooperating with co-workers & 55.0 \\
\hline Number of observations & 32861 \\
\hline
\end{tabular}

Source: OECD PIAAC survey Job Requirements Approach module 2011-12

Data from ECS and PIAAC JRA on these variables are used to categorise the SMEs into distinct classes of workplace organisation form using cluster and factor analyses. The information on SME workplace organisation forms is then crossed with information on SME innovation activities at the country and firm level using two different approaches. In the case of the ECS analysis, establishment-level information on the organisation of work is matched with information for the same establishments on indicators of product and process innovation based on Oslo Manual definitions. These data are used to undertake a micro-level econometric analysis exploring the impact of differences in SME organisational form on the likelihood that an establishment has successfully introduced a new product or process. In addition, correlation analyses are carried out at national level between shares of SMEs with different organisational forms and shares of SMEs participating in innovation activities using the results of the 2012 Community Innovation Survey (CIS-2012). These correlations are undertaken both for the ECS data and the PIAAC data.

\section{Data sources}

\section{Third European Company Survey}

The Third ECS is a harmonised employer survey carried out in 2013 at the establishment level in the EU-28 countries and the Republic of North Macedonia, Iceland, Montenegro and Turkey. Topics covered include work organisation, human resources practices, employee participation and social dialogue. Work organisation is examined from the perspective of how interactions are coordinated and monitored within the establishments and how knowledge is managed. The ECS also includes indicators of innovation 
performance based on Oslo Manual definitions. Box 2.1 provides further details on the survey. The analysis in this paper is restricted to the EU-28, Turkey and Iceland.

\section{Box 2.1. The Third European Company Survey}

The Third European Company Survey (ECS) was carried out from the Spring of 2013 by the European Foundation for the Improvement of Living and Working Conditions (Eurofound) in the EU-28, the Republic of North Macedonia, Iceland, Montenegro and Turkey. The target respondents were senior managers in charge of personnel in establishments with 10 or more employees in all sectors excluding agriculture, forestry and fishing; activities of the household; and activities of extraterritorial organisations and bodies. In all, over 30000 establishments were surveyed by Gallup Europe, with a target sample size per country ranging from 300 to 1650 . The survey was conducted on the basis of questionnaire-based telephone interviews of management and employee representatives in the national language(s) of the countries surveyed. The surveys used stratified simple random sampling without replacement in the case of countries that had an establishment-level sampling frame, and stratified multi-stage random sampling with replacement for countries with company-level sampling.

For details on the survey and sampling design, see $3^{\text {rd }}$ European Company Technical Report, European Foundation for the Improvement of Living Conditions, Dublin:

https://www.eurofound.europa.eu/sites/default/files/ef_files/surveys/ecs/2013/documents/ecs2013docs/3rdECS2013TechnicalReport.pdf

\section{OECD Programme for the International Assessment of Adult Competencies}

The OECD Programme for the International Assessment of Adult Competencies (PIAAC) is an internationally-harmonised employee-level survey targeting the adult population in selected OECD and non-OECD countries. ${ }^{10}$ The survey was designed to make direct assessments of adult skills in the domains of literacy, numeracy, and problem-solving in technologically-rich environments. ${ }^{11}$ The survey included a Job Requirements Approach (JRA) module designed to measure the generic skills employees use in work, based on questions asking them what they do in their jobs. These generic skills include learning skills, communication skills, the skills needed to work in teams and the skills needed to work more independently. The premise is that by focusing on job tasks, the JRA provides a more objective description of these skills than an approach relying on subjective selfassessments by individuals of the type and level of skills they possess. Box 2.2 presents details on the PIAAC survey design.

\footnotetext{
${ }^{10}$ In most countries the sampling frame was the national population registry. In some case twostage sampling was applied with frames of communities or municipalities in the first state and population registries at these levels in the second stage. See:

http://www.oecd.org/site/piaac/Technical\%20Report_Part\%204.pdf

11 The direct problem-solving assessments are based on computer simulation tasks designed to measure the ability to analyse various requirements of a task, define goals and plans, and monitor progress until task purposes are achieved. For an example, see http://www.oecd.org/site/piaac/Problem\%20Solving\%20in\%20TRE\%20Sample\%20Items.pdf
} 


\section{Box 2.2. The OECD Programme for the International Assessment of Adult Competencies (PIAAC) Survey}

Data collection for the first round of PIAAC was carried out between August 2011 and March 2012 in 23 OECD countries: Australia, Austria, Belgium (Flanders), Canada, the Czech Republic, Denmark, Estonia, Finland, France, Germany, Ireland, Italy, Japan, Korea, the Netherlands, Norway, Poland, Portugal, the Russian Federation, the Slovak Republic, Spain, Sweden, the United Kingdom and the United States. The target population for PIAAC consists of all non-institutionalised adults between age 16 and 65 (inclusive) who reside in the country at the time of data collection. The target population excludes adults in institutional collective dwelling units (or group quarters) such as prisons, hospitals and nursing homes, as well as adults residing in military barracks and military bases. The sampling frames for each country were required to include $95 \%$ or more of the standard PIAAC target population. For countries that are geographically large, the typical sample design is a stratified multistage clustered area sample. For participating countries that are geographically small, the sample design has less clustering and fewer stages of sampling.

For details on the survey and sampling designs, see Technical Report of the Survey of Adult Skills (PIAAC), OECD 2013.

http://www.oecd.org/site/piaac/_Technical\%20Report_17OCT13.pdf

\section{The Community Innovation Survey}

The CIS-2012 is a harmonised employer-level survey that was carried out at the enterprise level in the EU-28, Norway, Serbia and Turkey. The study includes indicators of the frequency with which a country's SMEs have developed products that are new to the market or world-first product innovations and the frequency with which both product and process innovations have been developed alone or in cooperation with other enterprises or organisations. 


\section{Results on SME organisational forms}

\section{European Company Survey analysis}

\section{Nature of the different SME organisational forms}

The factor and cluster analysis performed on the 11 variables in Table 2.1 identified 3 classes of SMEs corresponding to different organisational forms or designs, each accounting for about one-third of the sample for the EU-28, Turkey and Iceland. ${ }^{12}$ The nature of the classes is presented in Table 3.1.

Table 3.1. Organisational forms in SMEs: EU-28, Turkey and Iceland (ECS data)

Weighted percentage of establishments by organisational class

\begin{tabular}{|c|c|c|c|c|}
\hline \multirow[t]{2}{*}{ Variables } & \multicolumn{4}{|c|}{$\begin{array}{l}\text { Percent of establishments by organisational class reporting each } \\
\text { variable }\end{array}$} \\
\hline & $\begin{array}{l}\text { Learning } \\
\text { organisation }\end{array}$ & $\begin{array}{l}\text { HRM } \\
\text { hybrid }\end{array}$ & $\begin{array}{c}\text { Simple } \\
\text { organisation }\end{array}$ & Average \\
\hline \multicolumn{5}{|l|}{ Work organisation } \\
\hline $\begin{array}{l}\text { Employee has or shares responsibility for planning and } \\
\text { execution of tasks }\end{array}$ & 85.5 & 8.3 & 39.9 & 44.4 \\
\hline \multirow{3}{*}{ employees do not decide on division of tasks } & 47.1 & 0.2 & 10.5 & 19.0 \\
\hline & 38.8 & 80.2 & 35.8 & 51.8 \\
\hline & 69.8 & 76.2 & 52.8 & 66.3 \\
\hline Employees document and record good work practices & 74.0 & 75.2 & 31.2 & 60.3 \\
\hline Establishment monitors quality & 83.1 & 88.1 & 50.6 & 74.1 \\
\hline \multicolumn{5}{|l|}{ Employee involvement and consultation } \\
\hline Suggestion schemes & 54.0 & 49.0 & 18.9 & 40.8 \\
\hline Regular staff meetings open to all & 73.0 & 76.2 & 33.7 & 61.1 \\
\hline Regular meetings between employees and supervisor & 96.4 & 96.4 & 63.8 & 85.6 \\
\hline \multicolumn{5}{|l|}{ Training and incentives } \\
\hline On the job training during last 12 months ${ }^{*}$ & 55.6 & 45.4 & 17.0 & 39.4 \\
\hline Individual or group performance pay & 63.8 & 56.8 & 24.5 & 48.5 \\
\hline Performance appraisal once a year* & 81.6 & 62.4 & 22.8 & 55.7 \\
\hline All sample & 33.2 & 33.8 & 33.0 & 100.0 \\
\hline
\end{tabular}

Note: $* 40 \%$ or more of employees

Source: Analysis of Third European Company Survey, European Foundation for the Improvement of Living and Working conditions 


\section{The learning organisation SME}

The "learning organisation" class of SMEs corresponds to the model of the transformed/flexible organisation developed in the high performance workplace literature. The SMEs in this class are distinctive for combining organisational practices designed to make use of employees' knowledge and capacity for problem solving with complementary human resource management policies designed to provide incentives for employee involvement and commitment. The above average use of regular staff meetings and regular meetings between employees and their supervisors reflects the importance of horizontal communication as a liaison device in a relatively decentralised or flat organisational structure.

\section{The human resources management (HRM) hybrid SME}

The "human resources management (HRM) hybrid" SMEs can be distinguished from the learning organisation SMEs by their adoption of a relatively hierarchical organisational design, reflected in the very limited extent of delegation of responsibility for the planning of work execution to the employee level. While the proportion of HRM hybrid SMEs making use of team work is only slightly lower than for learning organisation SMEs, teams are organised in a hierarchical manner with the division of tasks being decided upon by management rather than by the team members. Job rotation, on the other hand, is used by a larger fraction of HRM hybrid than learning organisation SMEs, implying that this practice is not necessarily an indicator of how much responsibility or discretion employees exercise in their work. The various complementary human resources management practices, although at levels above that for the population of SMEs as a whole, are lower than in the case of the learning organisation and this is especially the case for the use of annual performance appraisal. There also is less use of on-the-job training as compared with the learning organisation SMEs.

\section{The simple organisation SME}

In the "simple organisation" class, all the employee discretion and involvement variables are under-represented. The frequency of pay and incentive devices designed to motive employee effort and commitment are the lowest across the three classes and only 17 per cent of the simple organisation SMEs provide their employees with on-the-job training. There is a predominance of individual over team work and where teams are present they tend to be organised in a top-down manner.

\section{Distribution of SME organisational forms by size and sector}

Table 3.2 presents the size distribution of SMEs in the three organisational classes. Both the learning organisation and HRM hybrid classes are relatively weighted towards mediumsized SMEs compared to the class grouping organisations with a simple design. Relatively small SMEs are more likely to make use of traditional forms of work organisation based on informal and non-codified systems.

\footnotetext{
12 The factor analysis used is multiple correspondence analysis. A hierarchical clustering analysis was performed on the first three factors accounting for 36.8 percent of the total variance of the dataset. The data are weighted.
} 
Table 3.2. Organisational forms by establishment size: EU-28, Turkey and Iceland (ECS data)

Weighted percentage of establishments by organisational class

\begin{tabular}{lcccc}
\hline & $\begin{array}{c}\text { Learning } \\
\text { organisation }\end{array}$ & $\begin{array}{c}\text { HRM } \\
\text { hybrid }\end{array}$ & $\begin{array}{c}\text { Simple } \\
\text { organisation }\end{array}$ & Total \\
\hline 10 to 49 employees & 31.3 & 30.6 & 38.1 & 100.0 \\
50 to 99 employees & 33.2 & 35.4 & 31.4 & 100.0 \\
100 to 249 employees & 39.4 & 38.7 & 21.8 & 100.0 \\
$N$ & 21035 & 21035 & 21035 & 21035 \\
\hline
\end{tabular}

Source: Analysis of Third European Company Survey, European Foundation for the Improvement of Living and Working conditions

Table 3.2 presents the distribution of SMEs in the three classes by main sector of activity. It shows that learning organisation SMEs are over-represented in knowledge-intensive business services, including the information and communication industries, the professional, scientific and technical industries and to a lesser extent finance and insurance. HRM hybrid SMEs are especially prevalent in manufacturing, construction and electricity, gas and water, and to a lesser extent in the accommodation and food industries. The simple organisation is especially characteristic of SMEs in transport and storage, real estate and to a lesser extent construction.

Table 3.3. Organisational forms by sector of activity: EU-28, Turkey and Iceland (ECS data)

Weighted percentage of establishments by organisational class

\begin{tabular}{|c|c|c|c|c|}
\hline Sector & $\begin{array}{c}\text { Learning } \\
\text { organisation }\end{array}$ & $\begin{array}{l}\text { HRM } \\
\text { hybrid }\end{array}$ & $\begin{array}{c}\text { Simple } \\
\text { organisation }\end{array}$ & Total \\
\hline Mining and manufacturing (ref) & 27.0 & 38.4 & 34.7 & 100.0 \\
\hline Electricity, gas and water & 32.8 & 42.9 & 24.3 & 100.0 \\
\hline Construction & 23.6 & 39.7 & 36.7 & 100.0 \\
\hline Wholesale and retail & 34.1 & 31.4 & 34.5 & 100.0 \\
\hline Transport and storage & 28.1 & 31.2 & 40.7 & 100.0 \\
\hline Accommodation and food services & 31.3 & 37.3 & 31.5 & 100.0 \\
\hline Information and communication & 50.7 & 25.4 & 24.0 & 100.0 \\
\hline Finance and Insurance & 45.9 & 33.8 & 20.3 & 100.0 \\
\hline Real estate & 39.9 & 22.0 & 38.0 & 100.0 \\
\hline Professional, scientific and & 49.5 & 26.7 & 23.8 & 100.0 \\
\hline Administrative and support & 37.1 & 31.8 & 31.1 & 100.0 \\
\hline Arts and entertainment & 38.9 & 27.1 & 34.0 & 100.0 \\
\hline Other services & 36.9 & 29.6 & 33.5 & 100.0 \\
\hline All sample & 33.2 & 33.8 & 33.0 & 100.0 \\
\hline
\end{tabular}

Source: Analysis of Third European Company Survey, European Foundation for the Improvement of Living and Working conditions 


\section{Frequency of organisational forms by country}

Table 3.4 shows that there are considerable differences in the frequencies of the three organisational classes across the EU-28, Turkey and Iceland. The share of learning organisation SMEs is generally high amongst the EU-15 countries. Learning organisations are most prevalent in the Nordic nations, reaching a maximum of 72 percent of all SMEs in Sweden, 70 percent in Finland and 62\% in Denmark. There are also fairly high shares of learning organisation SMEs in Austria, Germany, the Netherlands and Iceland. To a lesser extent, learning organisation SMEs are also over-represented in the United Kingdom and Ireland. Amongst central and eastern European countries there are relatively high shares of learning organisation SMEs in Slovenia and Estonia.

In contrast, there is an under-representation of SMEs adopting the learning organisation form in most of the southern European and central and eastern European countries. Of the EU-15, France, Spain, Italy, Greece and Portugal stand out for an under-representation of learning organisation SMEs. The HRM hybrid design is especially developed in Bulgaria, Romania, the Slovak Republic, Hungary and the Czech Republic as well as in Turkey. The simple organisation SME is overrepresented in Croatia, Lithuania, the Slovak Republic and Turkey and to a lesser extent in Hungary and Poland. 
Table 3.4. National differences in SME organisational forms: EU-28, Turkey and Iceland (ECS data)

Weighted percentage of establishments by organisational class

\begin{tabular}{|c|c|c|c|c|}
\hline \multicolumn{5}{|c|}{ Classes of organisational design } \\
\hline & Learning organisation & HRM hybrid & Simple organisation & Total \\
\hline Sweden & 72.3 & 15.8 & 11.9 & 100.0 \\
\hline Finland & 69.6 & 12.9 & 17.5 & 100.0 \\
\hline Denmark & 61.7 & 18.5 & 19.8 & 100.0 \\
\hline Austria & 61.3 & 19.9 & 18.8 & 100.0 \\
\hline Slovenia & 53.6 & 29.9 & 16.5 & 100.0 \\
\hline Germany & 47.0 & 25.6 & 27.4 & 100.0 \\
\hline Iceland & 45.3 & 24.4 & 30.3 & 100.0 \\
\hline Netherlands & 42.7 & 35.6 & 21.7 & 100.0 \\
\hline Ireland & 40.3 & 37.7 & 22.0 & 100.0 \\
\hline UK & 39.5 & 29 & 31.5 & 100.0 \\
\hline Estonia & 39.1 & 32.4 & 28.5 & 100.0 \\
\hline Luxembourg & 38.8 & 32.7 & 28.5 & 100.0 \\
\hline Cyprus & 32.4 & 36.8 & 30.8 & 100.0 \\
\hline Poland & 31.2 & 33.4 & 35.4 & 100.0 \\
\hline Malta & 30.3 & 35.9 & 33.8 & 100.0 \\
\hline Latvia & 30.3 & 39.4 & 30.2 & 100.0 \\
\hline Belgium & 29.2 & 31.5 & 39.3 & 100.0 \\
\hline Lithuania & 28.6 & 33.0 & 38.4 & 100.0 \\
\hline France & 27.9 & 32.6 & 39.4 & 100.0 \\
\hline Spain & 25.8 & 39.3 & 34.9 & 100.0 \\
\hline Greece & 25.6 & 39.1 & 35.2 & 100.0 \\
\hline Hungary & 24.2 & 40.7 & 35.1 & 100.0 \\
\hline Romania & 23.6 & 49.3 & 27.1 & 100.0 \\
\hline Italy & 22.3 & 35.7 & 42.0 & 100.0 \\
\hline Bulgaria & 20.9 & 45.9 & 33.2 & 100.0 \\
\hline Portugal & 20.1 & 46.2 & 33.7 & 100.0 \\
\hline Czech & 19.5 & 50.2 & 30.3 & 100.0 \\
\hline $\begin{array}{l}\text { Ronninlir } \\
\text { Turkey }\end{array}$ & 18.4 & 42.0 & 39.6 & 100.0 \\
\hline Slovak & 16.9 & 46.9 & 36.2 & 100.0 \\
\hline $\begin{array}{l}\text { Ranunlir } \\
\text { Croatia }\end{array}$ & 15.5 & 35.0 & 49.4 & 100.0 \\
\hline All & 33.2 & 33.8 & 33.0 & 100.0 \\
\hline
\end{tabular}

Source: Analysis of Third European Company Survey, European Foundation for the Improvement of Living and Working Conditions 


\section{Programme for the International Assessment of Adult Competencies analysis}

This section presents a complementary analysis of SME work organisation forms using employee-level data from the first wave of OECD's PIAAC survey developing a classification of SME work organisation types similar to that presented above based on the ECS. ${ }^{13}$

\section{Nature of the different SME organisational forms}

The analysis identifies three approximately equal-sized classes corresponding to different forms of SME work organisation and types of employee learning: the "discretionary learning", "constrained learning" and "simple" forms. The nature of the classes is presented in Table 3.5.

Table 3.5. Organisational forms in SMEs: 23 European and non-European countries (PIAAC data)

Percent of employees by work organisation class reporting each variable (weighted proportions)

\begin{tabular}{lcccc}
\hline Variable & Discretionary learning & Constrained learning & Simple & Average \\
\hline Discretion over how you do your work & 88.6 & 8.4 & 26.3 & 43.7 \\
Discretion over task sequence & 89.2 & 7.4 & 25.7 & 43.5 \\
Planning your own activities & 78.3 & 37.7 & 17.8 & 45.7 \\
Learning from tasks performed & 69.4 & 67.6 & 28.7 & 54.9 \\
Complex problem solving activity & 53.9 & 53.7 & 3.9 & 36.7 \\
Simple problem-solving activity & 86.6 & 95.4 & 26.8 & 68.7 \\
Sharing information with co-workers & 77.2 & 81.0 & 30.4 & 62.3 \\
Cooperating with co-workers & 56.5 & 69.7 & 41.0 & 55.0 \\
All sample & 36.6 & 29.3 & 34.3 & 100.0 \\
\hline
\end{tabular}

Source: Analysis of OECD PIAAC data

\section{The discretionary learning SME}

The discretionary learning SME is characterised by the combination of high levels of discretion and high levels of learning and problem-solving. Employees in this class of work organisation typically plan their own work activities. Information sharing is above the average for the population as a whole while cooperating with co-workers is at average levels. The forms of work organisation in this class of SME correspond rather closely to those found in adhocracies due to the combined importance of work discretion and learning. It is also very similar to the learning organisation class of SME identified through the ECS analysis.

13 The factor method used is multiple correspondence analysis. A hierarchical clustering analysis was performed on the first 4 factors accounting for 69.8 percent of the total variance of the data set. The data are weighted. 


\section{The constrained learning SME}

The constrained learning SME is characterised by high levels of employee learning and problem-solving in work. Discretion, however, is very low, with only 8 percent of employees in this class being able to choose or change how they do their work and only 7 percent being able to choose or change the task sequence. Thirty-eight percent of the employees report planning their own work activities as compared to 78 percent of employees in the discretionary learning cluster. The large majority of employees in this class report sharing information with co-workers and the percentage that cooperates with co-workers in their jobs is the highest across the three classes. The combination of high levels of learning and low discretion suggest a structured form of learning activity in which employees have relatively little scope for using their own ideas to explore possibly novel solutions to the problems they confront.

\section{The simple SME}

In this class, all the employee learning and discretion variables are under-represented compared to the population average. Cognitive demands are very low with only 4 percent of employees reporting that they engage in complex problem solving. Discretion, though higher than in the constrained learning SME, concerns only about a quarter of the employees. For the majority of employees, jobs are performed alone and information sharing is the lowest across the three classes. This class is likely to be capturing both traditional or hierarchical forms of work organisation associated with Taylorist methods and simple forms of work organisation found for example in personal services or in small retail shops.

\section{Distribution of SME organisational forms by size, sector and employee occupation}

Table 3.6 shows the distribution of the three forms of work organisation according to establishment size. There is very little difference in the relative importance of the three forms among different sizes of SMEs.

Table 3.6. Forms of work organisation by establishment size, small establishments; 23 European and non-European countries (PIAAC data)

Weighted percentage of employees by organisational class

\begin{tabular}{lcccc}
\hline$\%$ & Discretionary learning & Constrained learning & Simple & Total \\
\hline 10 to 49 employees & 36.6 & 29.8 & 33.6 & 100.0 \\
50 to 249 employees & 36.1 & 28.7 & 35.2 & 100.0 \\
All Sample & 36.4 & 29.3 & 34.3 & 100.0 \\
\hline
\end{tabular}

Source: Analysis of OECD PIAAC data

Table 3.7 shows the distribution of each form of work organisation according to broad sector of activity. The discretionary learning forms of work organisation are overrepresented in the knowledge intensive service sectors and to a lesser extent in electricity, gas and water and in arts and entertainment. This result compares to that found in the analysis of the ECS, where learning organisations were found to be over-represented in the 
knowledge intensive service and in electricity, gas and water. The constrained learning forms are especially developed in accommodation and food services and to a lesser extent in construction and in real estate. The simple forms are over-represented in transport and storage, administrative and support services and to a lesser extent in mining and manufacturing and in accommodation and food services.

Table 3.7. Forms of work organisation in SMEs by sector of activity; 23 European and nonEuropean countries (PIAAC data)

Weighted percentage of employees by organisational class

\begin{tabular}{lcccc}
\hline & Discretionary learning & Constrained learning & Simple & Total \\
\hline Mining and manufacturing & 35.6 & 26.1 & 38.2 & 100.0 \\
Electricity, gas and water & 43.4 & 25.5 & 31.1 & 100.0 \\
Construction & 35.8 & 33.5 & 32.7 & 100.0 \\
Wholesale and retail & 36.8 & 30.5 & 32.7 & 100.0 \\
Transport and storage & 27.1 & 26.9 & 46.0 & 100.0 \\
Accommodation and food services & 21.7 & 40.0 & 38.3 & 100.0 \\
Information and communication & 54.3 & 28.3 & 17.4 & 100.0 \\
Finance and Insurance & 47.9 & 32.7 & 19.4 & 100.0 \\
Real estate & 42.7 & 36.6 & 20.7 & 100.0 \\
Professional, scientific and technical & 50.2 & 25.6 & 24.2 & 100.0 \\
Administrative and support & 26.5 & 25.7 & 47.8 & 100.0 \\
Arts and entertainment & 44.5 & 22.5 & 33.0 & 100.0 \\
Other services & 44.9 & 25.6 & 29.4 & 100.0 \\
All sample & 36.4 & 29.3 & 34.3 & 100.0 \\
\hline
\end{tabular}

Note: Sectors correspond to ISIS Rev. 4

Source: Analysis of OECD PIAAC data

Table 3.8 shows the distribution of employees in the three SME organisational forms by occupational category. The majority of managers and professionals are grouped in the discretionary learning class. About one-half of technicians are in the discretionary learning class and a little less than one-third in the constrained learning class. The discretionary learning forms are under-represented amongst service and sales workers, plant and machinery operators and the elementary trades. The constrained learning forms are somewhat over-represented amongst craft and related traded and amongst service and sales workers. The simple form is especially characteristic of the work of plant and machinery operators and of the elementary trades. 
Table 3.8. Forms of work organisation in SMEs by occupational category: 23 European and non-European countries

Weighted percentage of employees by organisational class

\begin{tabular}{|c|c|c|c|c|}
\hline & $\begin{array}{l}\text { Discretionary } \\
\text { learning }\end{array}$ & $\begin{array}{l}\text { Constrained } \\
\text { learning }\end{array}$ & Simple & Total \\
\hline Managers & 69.4 & 16.6 & 14.0 & 100.0 \\
\hline Professionals & 56.7 & 24.4 & 18.8 & 100.0 \\
\hline Technicians & 50.5 & 31.4 & 18.1 & 100.0 \\
\hline Clerical Support Workers & 36.7 & 29.6 & 33.7 & 100.0 \\
\hline Service and Sales Workers & 26.5 & 33.5 & 39.9 & 100.0 \\
\hline $\begin{array}{l}\text { Skilled Agriculture, Forestry and Fishery } \\
\text { Workers }\end{array}$ & 35.7 & 31.5 & 32.8 & 100.0 \\
\hline Craft and Related Trades & 30.3 & 33.6 & 36.1 & 100.0 \\
\hline Plant and Machinery Operators & 17.9 & 29.5 & 52.6 & 100.0 \\
\hline Elementary Trades & 16.2 & 27.3 & 56.5 & 100.0 \\
\hline All sample & 36.4 & 29.3 & 34.3 & 100.0 \\
\hline
\end{tabular}

Source: Analysis of OECD PIAAC data

Table 3.9 shows the distribution of employees across the three forms of SME work organisation by level of formal education. About 45 percent of employees with postsecondary or tertiary education work in the discretionary learning forms whereas only about 20 percent of those with a lower secondary education or less do so. By contrast, the simple forms of work organisation are especially prevalent amongst employees with a lower secondary education or less.

Table 3.9. Forms of work organisation in SMEs by education level: 23 European and nonEuropean countries (PIAAC data)

Weighted percentage of employees by organisational class

\begin{tabular}{lcccc}
\hline & Discretionary learning & Constrained learning & Simple & Total \\
\hline & & & & \\
\hline Lower secondary or less & 19.9 & 30.3 & 49.7 & 100.0 \\
Upper secondary & 32.6 & 30.2 & 37.2 & 100.0 \\
Post-secondary or tertiary & 45.2 & 28.4 & 26.5 & 100.0 \\
All sample & 36.4 & 29.3 & 34.3 & 100.0 \\
\hline
\end{tabular}

Source: Analysis of OECD PIAAC data. 


\section{Frequency of organisational forms by country}

Table 3.10 shows the distribution of employees across the three forms of SME work organisation in the 23 countries that participated in the first wave of PIAAC. Amongst the European nations, the highest frequency of SME employees in the discretionary learning forms are found in the Nordic nations, Austria, Belgium, the Netherlands, the Czech Republic and to a lesser extent Estonia. Employment in discretionary learning SMEs is also over-represented in Japan where approximately 40 percent of employees are grouped in this cluster. The high rate of discretionary learning SMEs in the Nordic nations can be compared to the ECS findings, which showed high shares of learning organisation SMEs in the Nordic nations. The discretionary learning forms are at about average levels in the USA, the United Kingdom, Australia and Canada. The constrained learning forms are overrepresented in each of these four countries and in Ireland. These findings point to the relative importance of hierarchical forms of work organisation for SMEs in these countries. ${ }^{14}$ The simple form is especially characteristic of the Russian Federation, Korea, and Japan. Japan stands out for having an over-representation of both the discretionary learning and the simple forms.

Table 3.10. National differences in SME organisational forms: 23 European and nonEuropean countries (PIAAC data)

Weighted percentage of employees by organisational class

\begin{tabular}{|c|c|c|c|c|}
\hline$\%$ & Discretionary & Constrained learning & Simple & Total \\
\hline Sweden & 64.7 & 14.7 & 20.6 & 100.0 \\
\hline Finland & 58.9 & 12.8 & 28.3 & 100.0 \\
\hline Denmark & 53.3 & 16.2 & 30.5 & 100.0 \\
\hline Austria & 53.2 & 16.4 & 30.4 & 100.0 \\
\hline Belgium & 51.9 & 16.2 & 31.8 & 100.0 \\
\hline Czech Republic & 50.8 & 23.1 & 26.2 & 100.0 \\
\hline Norway & 50.1 & 20.1 & 29.8 & 100.0 \\
\hline Germany & 43.5 & 23.3 & 33.2 & 100.0 \\
\hline France & 42.2 & 26 & 31.8 & 100.0 \\
\hline Netherlands & 42 & 21.1 & 36.8 & 100.0 \\
\hline Estonia & 41.9 & 25.7 & 32.5 & 100.0 \\
\hline Japan & 39.9 & 15.4 & 44.7 & 100.0 \\
\hline Poland & 39.8 & 22.6 & 37.7 & 100.0 \\
\hline Spain & 38.2 & 31.6 & 30.2 & 100.0 \\
\hline Canada & 37.8 & 34.4 & 27.8 & 100.0 \\
\hline UK & 37.6 & 33.7 & 28.7 & 100.0 \\
\hline USA & 34.7 & 39.6 & 25.7 & 100.0 \\
\hline Australia & 33.4 & 32.6 & 34 & 100.0 \\
\hline Italy & 33.2 & 33.3 & 33.6 & 100.0 \\
\hline Ireland & 29.3 & 39.3 & 31.4 & 100.0 \\
\hline Slovak Republic & 28.9 & 39.4 & 31.7 & 100.0 \\
\hline Russian Federation & 25.7 & 30.1 & 44.3 & 100.0 \\
\hline Russian Federation & 25.7 & 30.1 & 44.3 & 100.0 \\
\hline Korea & 19.0 & 26.7 & 54.3 & 100.0 \\
\hline All sample & 36.4 & 29.3 & 34.3 & 100.0 \\
\hline
\end{tabular}

Source: Analysis of OECD PIAAC data 
Figure 3.1 below shows the correlations between the national frequency of the discretionary learning forms of work organisation and the frequency of the learning organisation design for the 16 European countries for which the data are available. For these countries there is a strong positive correlation between the frequency with which SMEs have adopted the learning organisation design and the frequency with which employees are engaged in forms of work organisation involving high levels of learning and discretion. Fully 70 percent of the variance in the national frequency of the discretionary learning forms can be accounted for by variations in the frequency of adoption of the learning organisation design. This result supports the hypothesis that the decisions made by SMEs on the adoption of specific types of organisational practices are closely connected to the extent to which their employees exercise discretion in how they learn and solve problems in their daily work activity.

\section{Figure 3.1. Correlation between adoption of the discretionary learning and learning} organisation forms

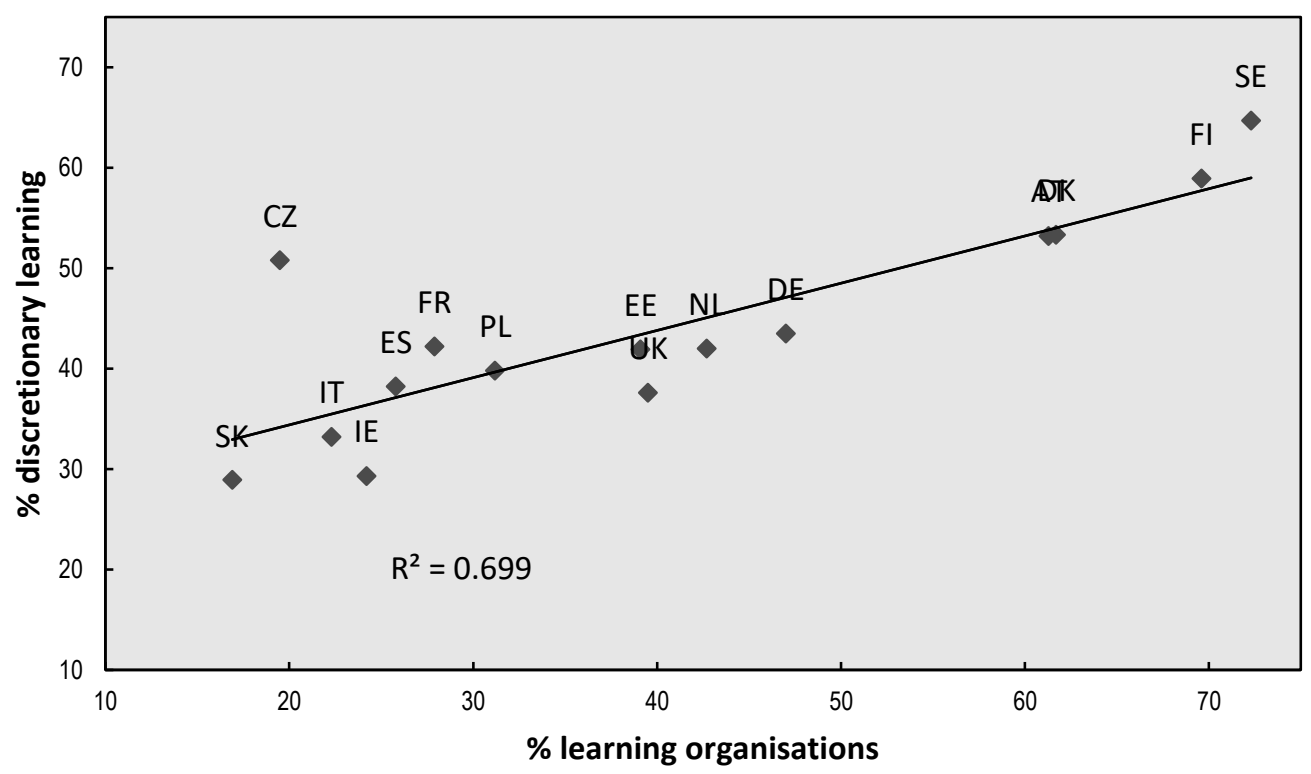

Source: Analysis of Third European Company Survey, European Foundation for the Improvement of Living and Working Conditions, and first wave of the OECD PIAAC survey

14 This difference in degree of hierarchical control over work in SMEs between the Anglo-Saxon nations and the Nordic as well as the Continental European nations has also been observed for enterprises more generally in the literature on the 'varieties of capitalism' (Hall and Soskice, 2001). 


\section{Results on relationships between SME organisational form and SME innovation}

\section{European Company Survey analysis}

\section{Firm-level regression analysis}

Key results from firm-level probit regression analyses of the impact of SME organisational form on SME innovation are provided in Tables 4.1 and 4.2. The impact of SME organisational form on the probability of an SME introducing a new product or service to the market over the last three years is shown in Table 4.1, while the impact on the probability of an SME introducing a new process is shown in Table 4.2. The first column in each table shows the results of the regression without controls and the second column shows the results with controls. The regression results can be seen to be very robust to the introduction of the set of controls for size, sector and whether the establishment is part of a multi-establishment enterprise. 
Table 4.1. Probit regression predicting product innovation outcomes from organisational form

\begin{tabular}{|c|c|c|}
\hline & \multicolumn{2}{|c|}{ New products or services } \\
\hline & No controls & With controls \\
\hline \multicolumn{3}{|l|}{ Organisational forms } \\
\hline $\begin{array}{l}\text { Learning organisation } \\
\text { HRM hybrid }\end{array}$ & \multicolumn{2}{|c|}{ Reference } \\
\hline Simple & $-.472^{* * *}$ & $-.464^{* \star *}$ \\
\hline Structural controls & & \\
\hline $\begin{array}{l}\text { Establishment size: } \\
10 \text { to } 49 \text { employees group) } \\
50 \text { to } 99 \text { employees } \\
100 \text { to } 250 \text { employees }\end{array}$ & & $\begin{array}{l}\text { Reference } \\
.065^{\star *} \\
.224^{\star \star *}\end{array}$ \\
\hline Part of multi-establishment company & & $.173^{* * *}$ \\
\hline $\begin{array}{l}\text { Sector: } \\
\text { Mining and manufacturing (reference } \\
\text { Electricity, gas and water } \\
\text { Construction } \\
\text { Wholesale and retail } \\
\text { Transport and storage } \\
\text { Accommodation and food services } \\
\text { Information and communication } \\
\text { Finance and Insurance } \\
\text { Real estate } \\
\text { Professional, scientific and technical } \\
\text { Administrative and support } \\
\text { Arts and entertainment } \\
\text { Other services }\end{array}$ & & $\begin{array}{c}\text { Reference } \\
-.389^{\star \star \star} \\
-.493^{\star \star \star} \\
.081^{\star \star} \\
-.438^{\star \star \star} \\
.023 \\
.429^{\star \star *} \\
-.070 \\
-.561^{\star *} \\
-.117^{\star \star \star} \\
-.228^{\star \star \star} \\
-.045 \\
-.195^{\star \star}\end{array}$ \\
\hline & $\begin{aligned} \text { Wald chi2 }(2) & =303.24 \\
\text { Prob }>\text { chi2 } & =0.00\end{aligned}$ & $\begin{aligned} \text { Wald chi2 }(45) & =935.79 \\
\text { Prob }>\text { chi } 2 & =0.00\end{aligned}$ \\
\hline$N$ & 21035 & 21035 \\
\hline
\end{tabular}

Note: *** significant at .01 level; **.05 level; *.10 level. The data are weighted. The column 2 regressions include controls for country. Odds ratios are compared to a reference group. 
Table 4.2. Probit regression predicting process innovation outcomes from organisational form

\begin{tabular}{|l|c|c|}
\hline & \multicolumn{2}{|c|}{ New processes } \\
\hline Organizational forms & $.100^{*}$ & $.112^{* * *}$ \\
\hline Learning organization & $-.508^{* * *}$ & $-.487^{* * *}$ \\
HRM hybrid & reference \\
\hline Simple & & Reference \\
\hline Structural controls & & $.123^{* * *}$ \\
10 to 49 employees & & $.271^{* * *}$ \\
50 to 99 employees & $.215^{* * *}$ \\
100 to 250 employees & & Reference \\
\hline Part of multi-establishment company & & -.135 \\
\hline Sector & & $-.393^{* * *}$ \\
Mining and manufacturing & & $-.181^{* * *}$ \\
Electricity, gas and water & & $-.264^{* * *}$ \\
Construction & & -.094 \\
Wholesale and retail & & .096 \\
Transport and storage & & .008 \\
Accommodation and food services & & $-.303^{* * *}$ \\
Information and communication & & $-.118^{* *}$ \\
Finance and Insurance & & $-.272^{* * *}$ \\
Real estate & & $-.249 * * *$ \\
Professional, scientific and technical & & .000 \\
Administrative and support & & Wald chi2 $(47)=1001.83$ \\
Arts and entertainment & & Prob $>$ chi2 $=0.00$ \\
Other services & & 21035 \\
\hline & & \\
\hline$N$ & & \\
\hline
\end{tabular}

Note: *** significant at .01 level; **.05 level; *.10 level. The data are weighted. The column 2 regressions include controls for country. Odds ratios are compared to a reference group.

The results show that SMEs with the learning organisation form have a greater probability than those with the HRM hybrid form both to have introduced a new product or service and to have adopted new processes. Simple organisations have a lower probability to have innovated in these ways. In terms of marginal effects, for the case of the product innovation regression with controls, a discrete change from the HRM hybrid form to the learning organisation form increases the probability of successful innovation by 3.1 percent. For the case of process innovation, it increases the probability of successful innovation by 4.2 percent.

The probability of product or service innovation increases with the size of the establishment and is significantly higher for establishments that are part of a larger multi-unit company. Using mining and manufacturing as the reference sector, goods or service innovations are more likely in the information and communication sector and to a lesser extent in wholesale 
and retail. There is no statistically significant difference compared to arts and entertainment, accommodation and food and finance and insurance. The probability of product or service innovation is less likely in the other sectors. In the case of process innovation, the probability is lower for most sectors compared to manufacturing and mining. There is no statistical difference in the probability for the case of information and communication, finance and insurance, and other services.

It is, of course, possible that there is simultaneity in the relation between innovation and organisational form. If the process of innovation itself leads management to delegate more decision-making responsibility to employees, then there could be a discrete move from the HRM hybrid or simple form of organisation towards a learning organisation form. This, in turn, by enhancing the SME's capacity for innovation in the future, could result in a reinforcing and cumulative process. The distance to travel would be greater however for an SME with a simple organisation form, since the low levels of investment in training to increase employee skills levels in such organisations would be an obstacle to delegating increased responsibility to them for the planning and execution of daily tasks. Whether such feedbacks occur will depend in part on how the process of innovation is organised. If innovation is organised linearly as a series of sequential steps, with the conception or design phase cleared before moving on to production and marketing, then the innovation process itself is unlikely to engender such reinforcing feedbacks between innovation and the learning organisation form. The cross sectional nature of the data available from the European Company Survey, however, precludes an exploration of these possible dynamic changes in organisational forms.

In the section that follows we turn to aggregate data at the national level and provide further evidence to support the view that the learning organisation form has a positive impact on innovation performance.

\section{National-level correlation analysis}

Figures 4.1 to 4.3 show correlations at national aggregate level for the EU-28 and Turkey between the frequencies of the three organisational forms and the frequency with which SMEs have introduced product and/or process innovation as measured by CIS-12. ${ }^{15}$ Consistent with the micro-level regression analysis, the results show that the share of SMEs that have introduced new products and/or processes tends to be higher in countries where there is a higher frequency of learning organisations. Innovation performance tends to lag in countries where a large share of SMEs has adopted either the HRM hybrid or the simple organisation form.

\footnotetext{
${ }^{15}$ Iceland did not participate in CIS-12.
} 
Figure 4.1. Correlation between national share of learning organisation SMEs and national SME innovation rates

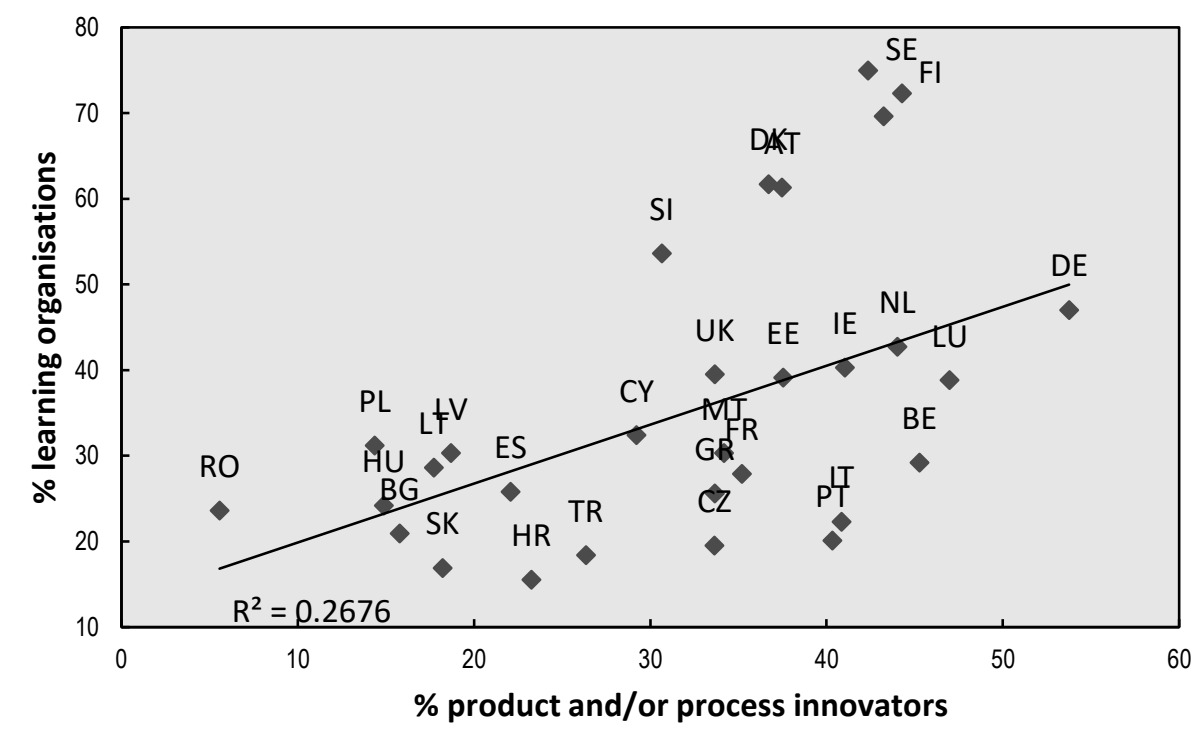

Source: Analysis of Third ECS and CIS-12

Figure 4.2. Correlation between national share of HRM hybrid SMEs and national SME innovation rates

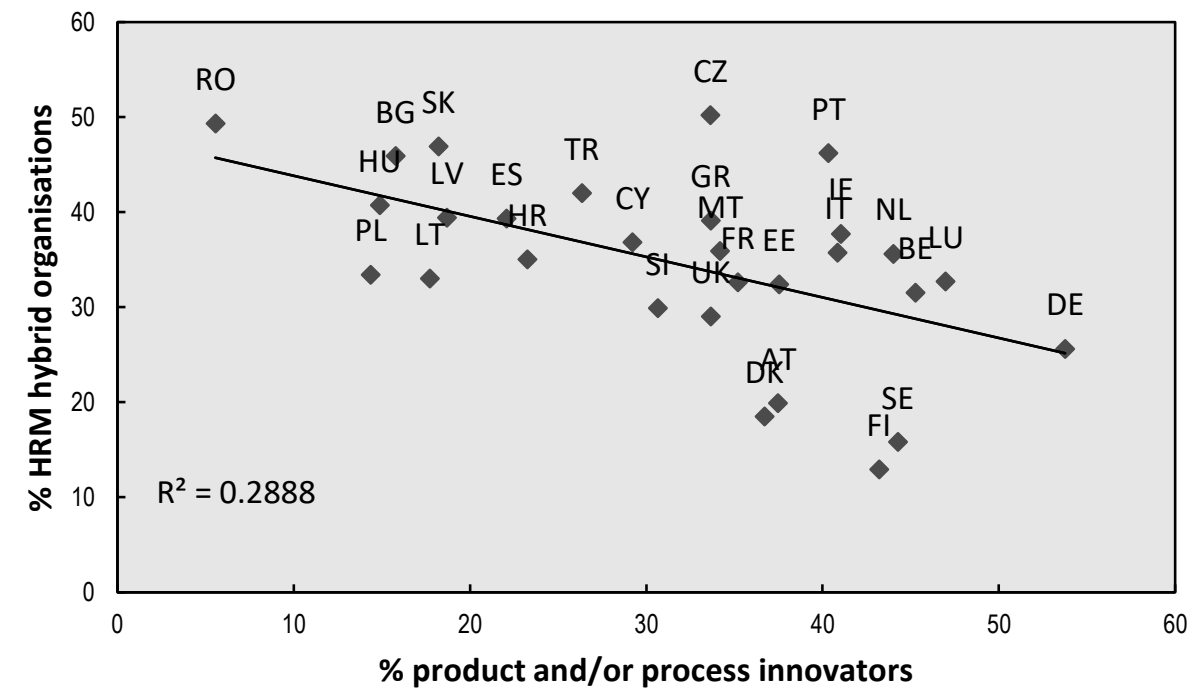

Source: Analysis of Third ECS and CIS-12 
Figure 4.3. Correlation between national share of simple organisation SMEs and national SME innovation rates

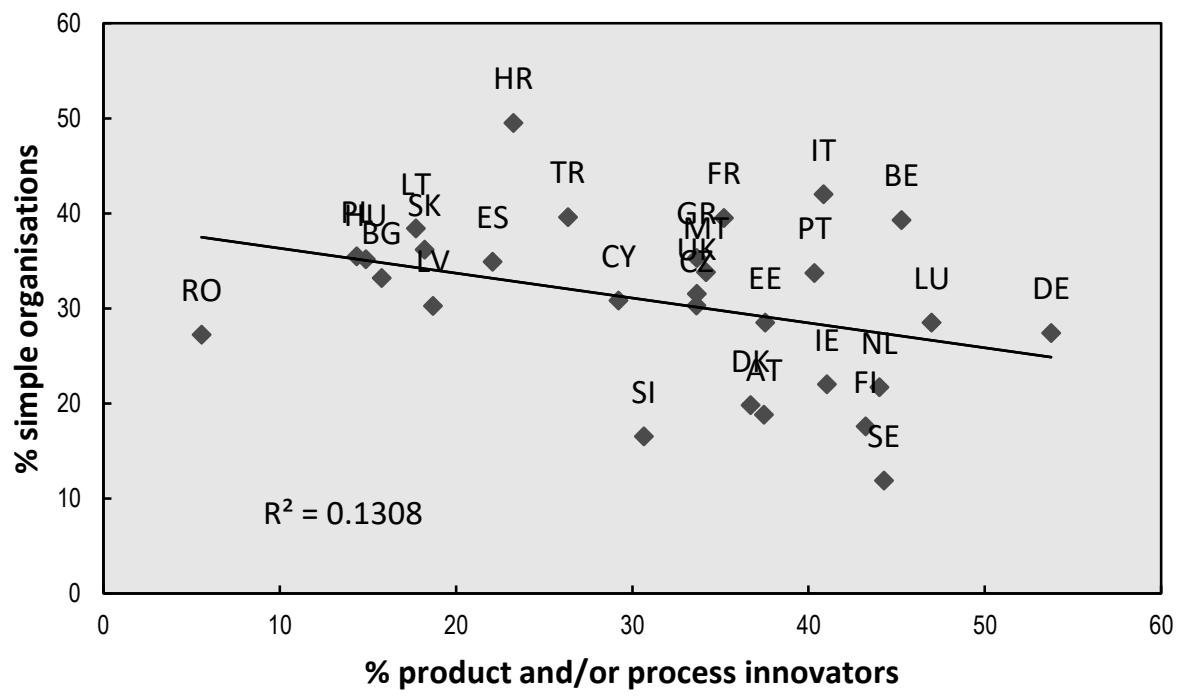

Source: Analysis of Third ECS and CIS-12

The figures in Table 4.3 extend the analysis firstly by showing separate correlation coefficients for the cases of product and process innovation and secondly by exploring the relation between organisational form and the degree of novelty of the innovation outcomes. The third row shows the correlation between the frequency of the different organisational forms and the frequency with which SMEs have introduced new products that are not only new-to-the-firm, the basic criterion in the Oslo manual for identifying innovators, but have also introduced products that are new to the firm's market. Since the SME's market may be strictly national, applying this filter or restriction does not preclude that the new product was originally produced by another firm or organisation. Nevertheless, the in-house innovation capabilities of SMEs that are first on their own market with a new product are likely to be greater than for those introducing products that are only new-to-the-firm. The fourth row shows the correlations between the frequencies of the organisational designs and the percentages of SMEs that have introduced products that are "world-first" products and hence reflect a high level of in-house creative capability.

The results show that the shares of SMEs that have developed both new-to-the-market and world-first products are higher in countries with a larger share of SMEs adopting the learning organisation design. The correlations are negative in the case of the national share of SMEs with a HRM hybrid or simple organisation form. These results point to a systemic relation between the adoption of specific organisational forms by SMEs within a country, and the frequency and novelty of SME innovation outcomes in that country. 
Table 4.3. Correlations between national frequencies of organisational forms and the shares of SMES that innovate by type of innovation: EU28 and Turkey

\begin{tabular}{lccc}
\hline \multicolumn{1}{c}{ Type of innovator: } & Learning organisation & HRM hybrid & Simple organisation \\
\hline CIS-2012: New product & & .53 & -.54 \\
CIS-2012: New process & & .38 & -.19 \\
CIS-2012: New-to-the-market product innovation & .32 & -.36 & -.36 \\
CIS-2012: At least one "world first" product & .51 & -.52 & -.30 \\
\hline
\end{tabular}

Note: Values unavailable for Poland, Netherlands, and Romania.

Source: Third European Company Survey, European Foundation for the Improvement of Living and Working conditions; 2012 Community Innovation Survey, Eurostat.

The figures in Table 4.4 show the relationship at the national aggregate level between the shares of SMEs with the three different organisational designs and the shares of SMEs that innovate entirely on their own or in cooperation with other firms or organisations. The results point to a positive relation between the diffusion of learning organisations and the frequency with which SMEs cooperate for purposes of innovation. Conversely, the share of SMEs that innovate on their own is higher in nations where the HRM hybrid or simple organisation forms are more frequent in SMEs.

Table 4.4. Correlations between national frequencies of organisational forms and shares of SME innovators that innovate on their own, in cooperation, or adapt innovations developed by other organisations

\begin{tabular}{lccc}
\hline Type of innovative activity & Learning organisation & HRM hybrid & Simple organisation \\
\hline Develops goods innovations on-own & -.26 & .21 & .25 \\
Develops goods innovations in cooperation & .46 & -.43 & -.37 \\
Develops process innovations on-own & -.30 & .28 & .24 \\
Develops process innovations in cooperation & .52 & -.51 & -.40 \\
\hline
\end{tabular}

Source: Third European Company Survey, European Foundation for the Improvement of Living and Working conditions; 2012 Community Innovation Survey, Eurostat.

Table 4.4 provides more information on inter-firm cooperation and partnerships by showing the correlations at the national aggregate level between the frequencies of the different organisational designs and the shares of innovative SMEs that cooperate with the following types of partners: suppliers, private sector clients, public sector clients, commercial laboratories, government or public research institutes, and universities. The results point to systemic relations between the frequency with which innovative SMEs cooperate and the extent to which SMEs have adopted different organisational designs. Inter-organisational co-operation and knowledge exchange are more developed in countries where a larger share of SMEs has adopted the learning organisation design. This is especially the case for innovative SMEs cooperating with universities and with government or public research institutes. 
Table 4.4. Correlations between the national frequencies of organisational forms and the shares of SME product and/or process innovators that co-operate by type of partners

\begin{tabular}{lccc}
\hline \multicolumn{1}{c}{ Type of cooperation } & Learning organisation & HRM hybrid & Simple organisation \\
\hline Any type of cooperation & .29 & -.32 & -.17 \\
Suppliers & .27 & -.28 & -.19 \\
Private sector clients ${ }^{2}$ & .40 & -.41 & -.29 \\
Public sector clients & & & -.46 \\
Commercial labs & .46 & -.46 & -.36 \\
Universities & .47 & -.50 & -.31 \\
Government or public research institutes & & -.54 & -.34 \\
\multicolumn{1}{c}{$n$} & .54 & -.54 & -.34 \\
\hline
\end{tabular}

Note: Values unavailable for Poland, Netherlands, and Romania. 2: Values unavailable for Poland. 3: Values unavailable for Sweden.

Source: Third European Company Survey, European Foundation for the Improvement of Living and Working Conditions; 2012 Community Innovation survey, Eurostat.

\section{Programme for the International Assessment of Adult Competencies analysis}

\section{National-level correlation analysis}

Figures 4.4-4.6 show the aggregate national correlations between the frequencies of the three forms of work organisation identified in factor and cluster analysis of the PIAAC data (discretionary learning, constrained learning and simple) and the national frequency of SMEs that have introduced new products onto the market. The innovation figures are based on the results of CIS-12 for the European nations and on national surveys adopting the Oslo Manual norms for the non-European nations. The results cover 21 countries and exclude the United States, the only OECD country participating in PIAAC that has not undertaken a national innovation survey based on the Oslo Manual norms.

The results show a positive correlation between the frequency of the discretionary learning forms and the frequency of product innovators. The Nordic nations lie above the least squares regression line reflecting a higher rate of adoption of the discretionary learning forms than would be predicted by the regression. Australia, Canada, the UK and Ireland lie below the line. The frequencies of the constrained learning and simple organisation forms are weakly negatively correlated with the frequency of product innovations at country level. In the case of the correlation with the simple forms, Korea and Japan are outliers. 
Figure 4.4. Correlation between national share of discretionary learning SMEs and national SME product innovation rates

21 European and non-European countries (PIAAC data)

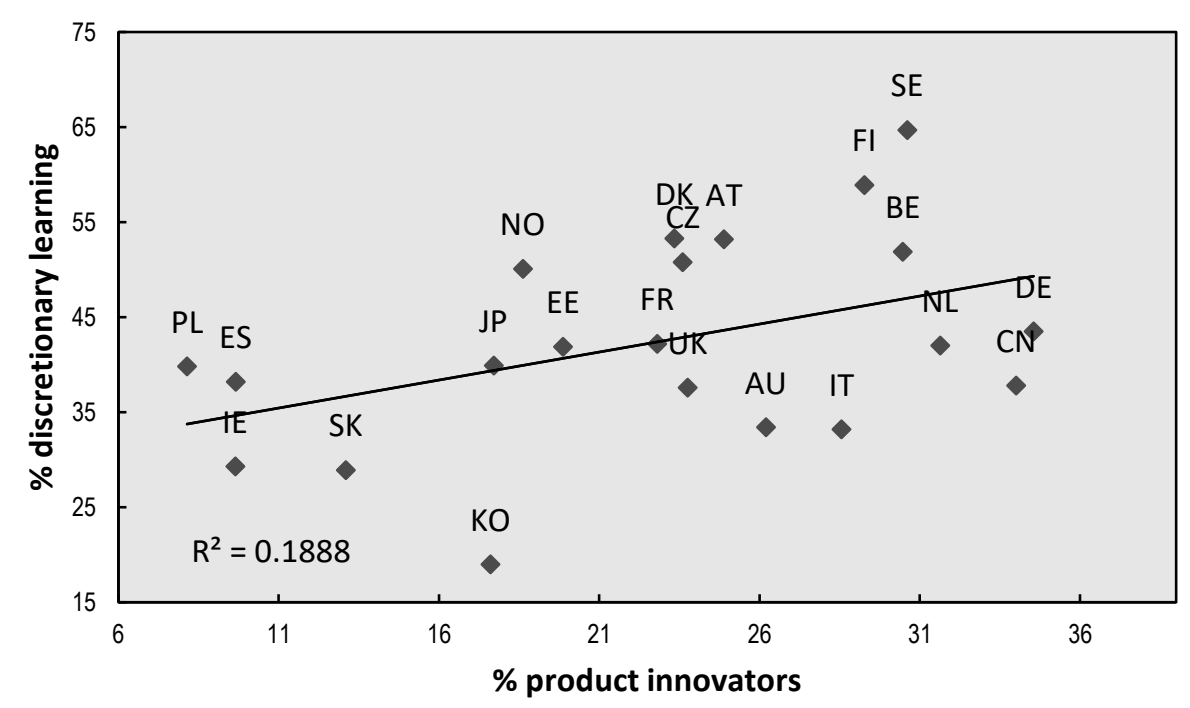

Source: Analysis of PIAAC Job Requirements Approach module, CIS-12 and national innovation surveys

Figure 4.5. Correlation between national share of constrained learning SMEs and national SME product innovation rates

21 European and non-European countries (PIAAC data)

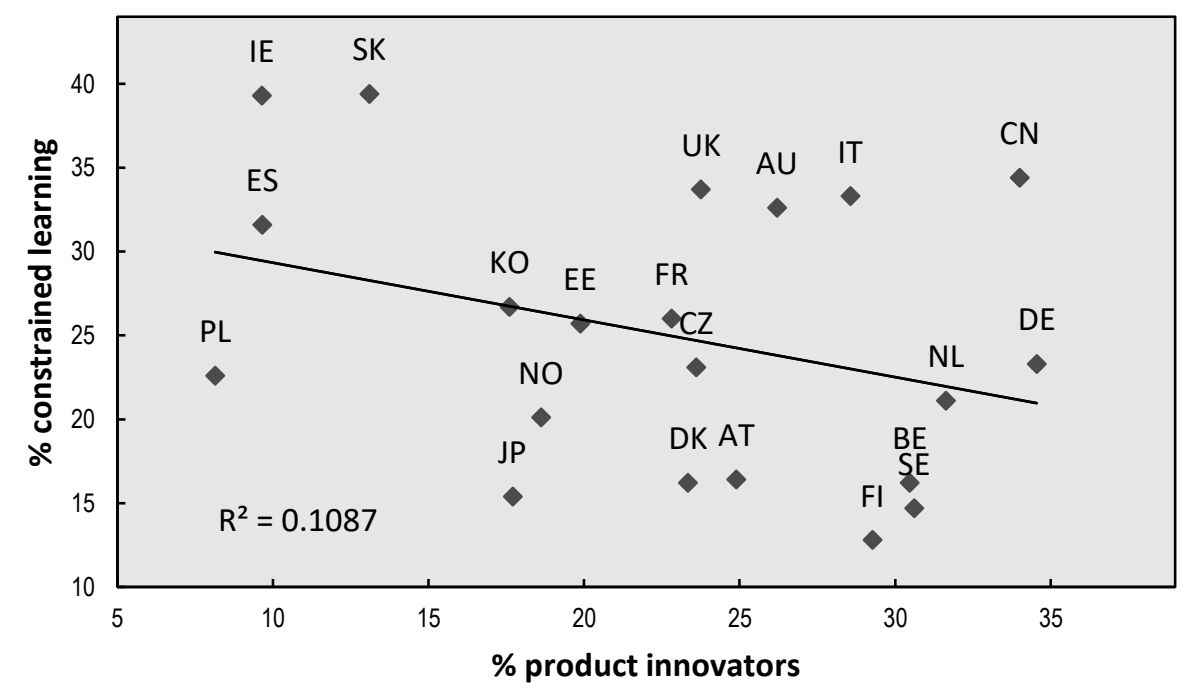

Source: Analysis of PIAAC Job Requirements Approach module, CIS-12 and national innovation surveys 
Figure 4.6. Correlation between national share of simple SMEs and national SME product innovation rates

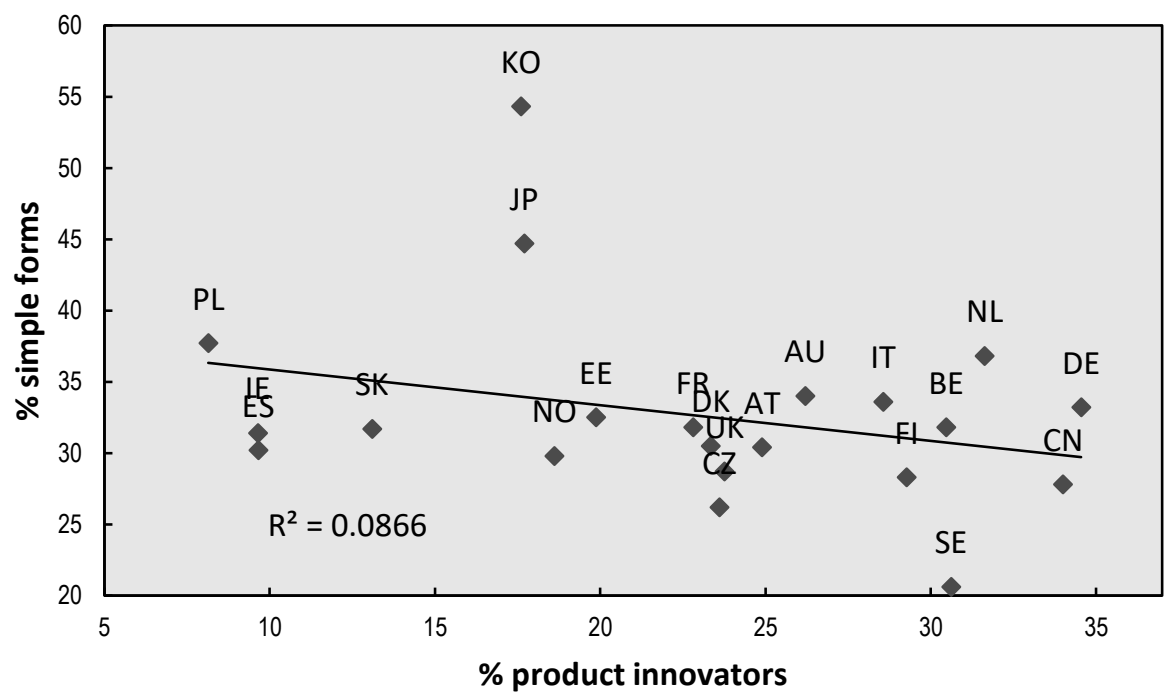

Source: Source: Analysis of PIAAC Job Requirements Approach module, CIS-12 and national innovation surveys

Table 4.5 shows the aggregate correlation across the 21 countries between national frequencies of different forms of SME work organisation and frequencies of product and process innovators. Although the results are at the national aggregate level and cannot demonstrate causation, they show that in countries where a large share of employees in SMEs are given discretion in solving the problems they confront in work, the share of SMEs introducing new products and processes tends to be higher. In countries where discretion and learning activity is constrained or relatively weak, the innovation performance of SMEs tends to lag.

Table 4.5. Correlations between the national frequencies of forms of work organisation the shares of SMES that innovate by type of innovation

\begin{tabular}{|c|c|c|c|}
\hline Type of innovator: & Discretionary learning & Constrained learning & Simple \\
\hline New product ${ }^{1}$ & 43.5 & -33.0 & -29.4 \\
\hline New process ${ }^{1}$ & 41.7 & -31.1 & -28.9 \\
\hline
\end{tabular}

Note: Values unavailable for Poland, Netherlands, and Romania.

Source: 2012 Community Innovation survey, Eurostat and national innovation surveys. 
Table 4.6 focuses on those SMEs that innovate and the types of collaboration partners they have. It shows that in countries where a large share of SME employees exercise discretion in their learning and problem-solving activity on the job, innovative SMEs are more likely to engage in innovation co-operation with a variety of partners. The results can be compared to those presented in Table 4.4 based on the ECS and can be interpreted in a similar manner. Due to the high levels of autonomy and discretion in the discretionary learning work organisation forms, employees have considerable opportunity for exploring novel solutions to the problems they face in their daily work activity. This greater scope for knowledge exploration can result in ideas contributing to the development of new products or processes or to the improvement of existing ones. In countries where SMEs emphasise the discretionary learning forms of work organisation with the objective of promoting the exploration of new knowledge, it is also likely that they will be interested in developing multiple forms of inter-firm co-operation in order to increase their employees' access to new external sources of knowledge that can be used in the development of new products and processes.

Table 4.6. Correlations between the national frequencies of forms of work organisation and the shares of SME product and/or process innovators that collaborate by type of partners

\begin{tabular}{lccc}
\hline \multicolumn{1}{l}{ Type of cooperation: } & Discretionary learning & Constrained learning & Simple \\
\hline Any type of collaboration & 31.6 & -30.9 & -15.8 \\
International collaboration & 41.5 & -17.7 & -50.9 \\
Suppliers & 43.6 & -35.0 & -30.3 \\
Clients $^{1}$ & 29.4 & -22.2 & -21.8 \\
Higher educational establishments & 43.6 & -35.0 & -30.3 \\
\hline
\end{tabular}

Source: 2012 Community Innovation survey, Eurostat and national innovation surveys. 


\section{Conclusions and policy implications}

This paper investigates the relationship between SME innovation performance and the workplace organisation characteristics of SMEs in a range of OECD countries using differing and complementary information sources and methodological approaches. It identifies a close connection between the organisational design of SMEs and their innovation performance. Firm-level regression shows that SMEs adopting work practices favouring employee discretion over planning tasks, team work, opportunities for problemsolving activity, and incentives for employee involvement and commitment are more likely than other SMEs to innovate. National-level correlation analyses confirm that countries with larger shares of SMEs with such learning organisation or discretionary learning organisational designs have larger shares of SMEs that innovate and that collaborate with other organisations in innovation.

The paper also identifies important differences across countries in the prevalence of the forms of SME work organisation that favour innovation. In Europe, the share of SMEs with learning organisation designs ranges from approximately 70 percent in Sweden and Finland to only 20 percent or less in Portugal, Bulgaria and Croatia. Similarly, the share of employees in SMEs with discretionary learning work designs ranges from 65 percent in Sweden and 59 percent in Finland to less than 30 percent in Ireland, the Slovak Republic, the Russian Federation and Korea.

The results point to the relevance of widening the focus of policy efforts to encourage SME innovation from the encouragement of R\&D activity to include the role played by the work environment and the types of organisational practices adopted by firms in translating human capital into innovation. As discussed in Arundel et al. (2007, p. 1204), the results point to the need for policies promoting the adoption of "pro-innovation" organisational practices, especially in countries that are behind in terms of innovation performance and that have tended to focus their policy efforts on R\&D intensity. The bottleneck to improved innovation performance may not be low levels of $R \& D$, which are strongly determined by industrial structure and consequently slow to change, but the widespread presence of working environments that do not provide a fertile environment for innovation (Lorenz, 2004).

Business development services policies offer one route for stimulating more SMEs to introduce workplace organisation methods that favour innovation by offering advice, consultancy and mentoring in this area to management teams in SMEs that have ambition to develop and grow (OECD, 2018).

A second route is to introduce financial and technical support designed to promote workplace change. A number of countries have introduced such programmes. In Europe, Alasoini et al. $(2006,2009)$ identify and evaluate ten national and regional programmes in seven countries, while Ramstad (2005, 2008) identifies Norway, Sweden, Finland and Germany as frontrunner countries in policies for organisational innovation. The programmes differ in the extent to which they give primary emphasis to SMEs. There are also different types of approaches, with a contrast between approaches that centre on publicising and disseminating the practices of few 'model' enterprises as compared with a 
more 'generative' approach based on supporting bottom-up initiatives involving managers and workers in the implementation of organisational changes through a competitive grant process open to large numbers of SMEs, including networks of SMEs.

Finland provides one of the better examples of the 'generative' approach to workplace innovation policy involving a succession of major programmes over the last two decades. Between 1996 and 2010 more than 1800 projects were funded through the TYKE and TYKES programmes, involving nearly 350000 employees and some EUR 106 million of public funding. Over 1500 of the projects consisted of development projects started at the initiative of local workplaces. Typical objectives included improving work processes, organisation of work, supervisory tasks, work community, working methods and businessto-business networks (see Box 5.1). More recently, the Liideri Programme was introduced in 2012 under the leadership of the Ministry of Employment and Economy. This programme provides financial support for projects on management principles and processes, employee-driven innovation and new ways of working and focuses primarily on SMEs pursuing innovation-based growth. The programme's initial goal was to fund at least 300 projects, of which at least $70 \%$ should bring about clear and measurable improvements in productivity and well-being at work (Alasoini, 2015).

\section{Box 5.1. The Finnish Workplace Development Programme (TYKE and TYKES)}

The Finnish programmes TYKE (1996-2003) et TYKES (2004-2010) are amongst the most ambitious national government programmes developed within Europe to promote the adoption of innovative forms of work organisation. Both programmes aimed to promote the introduction of organisational innovations contributing to improvements in workplace productivity and the quality of working life through tailored and demand-based activities. ${ }^{16}$

The programmes were initially implemented by the Ministry of Labour and then transferred in 2007 to a project team within Tekes (the Finnish funding agency for technology and innovation), with support of an advisory scientific expert forum and a regional network in local Employment and Economic Development Centres and Occupational Safety Districts.

The programmes mainly focused on funding "development projects" implemented at the initiative of the workplaces concerned. The first generation programme, TYKE, funded 670 projects involving 135000 persons and an estimated 1600 workplaces. The second generation programme, TYKES, involved expanded resources, awarding funding of approximately EUR 71 million to some 1200 projects, including 1000 developed at the initiative of workplaces, covering over 3000 workplaces, and a total of 207000 persons.

Some two-thirds of the TYKES development projects were in private workplaces, with the remainder in the public sector. Approximately two-thirds of the funding for private sector projects went to SMEs. SME participation was encouraged by the possibility to participate in projects as part of a broader network. Hence, in about $40 \%$ of the development projects, there was more than one workplace participating. The financial investment from the

\footnotetext{
16 The description of these programs presented here is based primarily on the recent report prepared by Tuomo Alasoini (2019) of the Finnish Institute of Occupational Health and the final report of TYKES prepared by the executive management team (Tykes, 2011). Also see: Alasoini et al. (2005) and Ramstad (2009).
} 
workplaces themselves in development projects was estimated to be at least double that of the programme investment.

The most common areas of focus for the development projects were work processes, the organisation of work and the development of human resource management and supervisory work. In addition, a smaller number of feasibility studies were funded as network projects, which in the case of TYKE concerned several companies and focused on introducing organisational innovations and employment growth (Alasoini, 2019, pp. 11-13).

Ramstad (2014) discusses how the development projects were implemented. Project implementation was in close cooperation between management and employees within each workplace. External experts were to be used in each project. In more than $60 \%$ of cases, the experts were private consultants, whereas $20 \%$ came from universities or governmental research institutes and the remainder from lower-level educational institutes. Typical methods used in the projects were various types of analysis and mappings, development groups, interviews, coaching, process consulting, action research, team training, and process analyses.

Both programmes were monitored though self-assessment surveys directed to management representatives, employee representatives and external experts. The questionnaire focused on the impact of the projects on the operational performance of workplaces (including issues of decentralised decision-making, employee competence development, the role of supervisors in supporting employees, and internal and external cooperation of the workplace as well as productivity and employment), as well as the impacts on quality of working life and equality in the workplace.

In the case of TEKES, approximately $70 \%$ of managers reported that development projects had positive impacts on the operational performance of the workplace, ranging from $65 \%$ to $75 \%$ depending on the indicator concerned. Approximately 50\% of staff reported positive impacts on quality of work (Tykes, 2011). Further analysis by Ramstad (2014) found that decentralised decision-making, employee competence, and internal and external cooperation were positively associated with simultaneous improvements in productivity and quality of work. There was a particularly strong effect from decentralised decision making (whereby decision-making was decentralised to a team-level activity). Some key project features were associated with success, namely active employee and middle management participation in the planning and implementation phases of the project, close internal collaboration during the process, competence in project work, methods used by the external expert, and external networking.

Both programmes were also subject to external assessment. TYKE was evaluated by the consulting group Social Development Company Ltd., which reached similar conclusions to those of the self-assessment exercise concerning the impact and success of the programme (see Rissanen et al. 2003). The TYKES program was externally evaluated in 2010 by the Ramboll Finland Management Consulting. The report concluded that TYKES was successful in raising public awareness of the importance of workplace change and innovation in Finland; in boosting development activity among a large group of Finnish workplaces including SMEs; and more generally in strengthening expertise on workplace development and research on working life among universities, research institutes and other R\&D organisations

The final report of the executive team (Tykes, 2011) argued that: 
- The projects demonstrated that it is possible to improve productivity and the quality of working life at the workplace level simultaneously.

- The experience of the projects showed that this required broad-based participation of staff in development, and genuine supporting dialogue between management and staff.

- Utilisation of employees' skills and competences, initiative and creativity in innovation was supported by close interaction between strategic human resource management and innovation management as well as interaction between the employer and employee sides in workplace development projects.

Sources: Alasoini (2019); Tykes (2011); Ramstad (2014).

Further references: Alasoini, Ramstad and Rouhiainen (2005); Ramstad (2009); Rissanen, Pitkänen, and Arnkil (2003).

Sweden offers another example of a long-term approach to policies supporting workplace innovation in SMEs. The Working Life Fund Programme (1990-1995) spent SEK 10 billion on 25000 workplace improvement projects, reaching about half of the total labour force (Gustavsen 2007; Gustavsen 1996). More recently, VINNOVA (the Swedish Agency for Innovation Systems) has run six programmes relating to work organisation including Competent Workplace (2007-2011) and Winning Services (2009-2013). The programmes involve calls for proposals to enterprises for participation in research projects relating to workplace organisation and strategic management to identify how the experience, expertise and development ideas of staff can be fostered and utilised within the organisation (VINNOVA, 2009).

\section{Box 5.2. Swedish Programmes for Workplace Innovation}

The Swedish government has pursued programmes to support workplace innovation for many years. Some of the programmes are discussed below.

The Working Life Fund Programme (1990-1995)

The Working Life Fund (Arbetslivsfonden) was set up with the proceeds of a special 1.5\% payroll tax levy imposed over 16 months in 1989-1990 as an anti-inflation measure (Gustavsen et al, 1996). The Fund supported projects to improve working life from 19901994. Employers could apply to the Fund for grants for project activities, with the Fund paying 50\% of the project costs and the employer the other 50\%. Expenditure of SEK 10 billion was made, supporting approximately 25000 projects involving about 2 million workers (approximately half of the Swedish workforce). Most of the projects were in individual workplaces but cross-employer network projects were also funded. The main contribution of the programme was financial support to employers for organisation change initiatives, since the knowledge and capacities for change were thought to exist in the system.

Some 24 regional offices were established to support the programme delivery, including the functions of raising awareness of the programme, advising on the design of projects, selecting the projects for funding and disseminating project results to other employers. Approximately half of the investments were in work organisation projects with the aim of 
improving workplace productivity with other projects focused on other issues such as health. Both large and small firms participated as well as public sector employers.

An evaluation of the Fund found a strong positive correlation between work organisation and improvements in productivity. It also found a positive relationship between the ability to change work organisation and the degree of participation of different categories of people - managers, supervisors, unionists, and workers - in the projects (Gustavsen, 2007).

\section{Competent Workplace Programme (2007-2011)}

This programme involved funding from VINNOVA (the Swedish research and innovation agency) for research about the competent workplace. A total of 19 research projects received funding awards of between SEK 675000 and SEK 4.5 million through a call for projects open to universities, colleges, research institutes and research departments in companies. The research projects were to be carried out in collaboration with companies and other organisations (Döös and Larsen, 2008).

The aim of the research projects was to investigate how to reorganise the workplace, with a focus on supporting interactions in the workplace that develop knowledge sharing, collective competences, relationships and networks. Both large and small firms participated. Each research project aimed to benefit the participating companies as well as the wider business community. Examples of research themes include - knowledge sharing in knowledge-intensive organisations, collective competence and small-scale innovations, competitive project activities, organisational skills, relationships and networks for leadership and sustainability, and integrating consultants into processes of practical knowledge integration in client firms. A common approach was for small numbers of companies (e.g. 4-5) to participate in a research project as case studies, although larger numbers could be involved. The research proposals needed to set out a plan of how the project results would be used in the participating companies.

\section{Winning Services Programme (2009-2013)}

Through this programme, VINNOVA invested just over SEK 40 million in 10 research projects on how service operations can be managed and organised so that the employees' experiences, skills and development ideas contribute to new or improved work processes and services offerings (VINNOVA, 2010). The aim was to improve work organisation in participating companies, both through the application of science-based knowledge and employee experience and development ideas. Results were also to be disseminated to other companies, for example through corporate networks and consulting.

Some 63 applications for funding were received from a call for research proposals. A panel of researchers, businesses and government representatives assessed the proposals and 10 projects were selected. Examples of projects include - how waste management companies organise their operations and collaborate to create new services, how employee ideas are handled in a retailer, how service companies are managed, how to integrate stakeholders such as managers, employees, consultants, customers and suppliers into open innovation environments and new approaches to leadership for developing services innovations through interactions between employees and customers/users.

Sources: Gustavsen (1996, 2007); Döös, M. and Larsen, P. (2008); VINNOVA (2010)

This type of active policy support for change in the workplace could be influential in stimulating the adoption of more pro-innovation organisational designs by SMEs in a wider range of countries and hence in stimulating greater SME innovation. 


\section{References}

Alasoini, T. (2006), "In search of generative results: a new generation of programmes to develop work organization”, Economic and Industrial Democracy, Vol. 27.1, pp. 9-37.

Alasoini, T. (2009), "Strategies to promote workplace innovation: a comparative analysis of nine national and regional approaches", Economic and Industrial Democracy, Vol. 30.4, pp. 614-642.

Alasoini, T. (2015), "Two decades of programme-based promotion of workplace innovation in Finland: past experiences and future challenges", European Journal of Workplace Innovation, Vol. 1.1.

Alasoini, T. (2019) 'The Promotion of Workplace Innovation in Finland: Policy Developments and Outlook for the Future'. Report to the Finnish Institute of Occupational Health. Finnish Institute of Occupational Health, Helsinki.

Alasoini, T., A. Heikkilä, E. Ramstad and P. Ylöstalo (2008), "High-involvement innovation practices at Finnish workplaces", International Journal of Productivity and Performance Management, Vol. 57.6, pp. 449-459.

Alasoini, T., Ramstad, E. \& Rouhiainen, N. (2005) Finnish Workplace Development Programme as an expanding activity: results, challenges, opportunities. Reports of the Finnish Workplace Development Programme 47. Helsinki: Ministry of Labour.

Appelbaum, E., T. Bailey, P. Berg, and A. L. Kalleberg (2000), Manufacturing Advantage: Why HighPerformance Work Systems Pay Off. Cornell University Press, Ithaca, New York.

Arundel, A., E. Lorenz, B. Å. Lundvall and A. Valeyre (2007), “How Europe’s economies learn: a comparison of work organization and innovation mode for the EU-15", Industrial and Corporate Change, Vol. 16.6, pp. 1175-1210.

Becker, B., and B. Gerhart (1996), "The impact of human resource management on organizational performance: progress and prospects", Academy of Management Journal, Vol. 39.4, pp. 779-801.

Becker, B. E. and M. A. Huselid (1998), "High performance work systems and firm performance: a synthesis of research and managerial implications", Research in Personnel and Human Resources Management, Vol. 16, pp. 53-101.

Burns, T. E. and G. M. Stalker (1961), The Management of Innovation. University of Illinois at UrbanaChampaign's Academy for Entrepreneurial Leadership Historical Research Reference in Entrepreneurship.

Döös, M. and Larsen, P. (2008), Den kompetenta arbetsplatsen - Forskning om kompetens i arbetsplatsens relationer. Programkatalog. Vinnova Information VI 2008:16. Vinnova, Stockholm.

Erickson, C. L. and S. M. Jacoby (2003), "The effect of employer networks on workplace innovation and training”, Industrial and Labor Relations Review, Vol. 56.2, pp. 203-223.

El-Ella, N., M. Stoetzel, J. Bessant and A. Pinkwart (2013), "Accelerating high involvement: the role of new technologies in enabling employee participation in innovation", International Journal of Innovation Management, Vol. 17.06.

Fitjar, R. D. and A. Rodríguez-Pose (2013), "Firm collaboration and modes of innovation in Norway", Research Policy, Vol. 42.1, pp. 128-138.

Freeman, R. B. and E. P. Lazear (1995), "An economic analysis of works councils”, in Rogers, J. and W. Streeck (eds), Works Councils. Consultation, Representation, and Cooperation in Industrial Relations, University of Chicago Press, Chicago. 
Fricke, W. and P. Totterdill (Eds.) (2004), Action Research in Workplace Innovation and Regional Development (Vol. 15), John Benjamins Publishing, Amsterdam.

Greenan, N. and E. Lorenz (2013), "Developing harmonised measures of the dynamics of organisations and work", in F. Gault (ed.) Handbook of Innovation Indicators and Measurement, Edward Elgar, Cheltenham.

Gustavsen B. (2007), "Work organization and the 'Scandinavian Model', Economic and Industrial Democracy, Vol. 28.4, pp. 650-671.

Gustavsen B., Hofmaier, B., Philips, M. E. and Wikman, A. (1996), Concept-Driven Development and the Organisation of the Process of Change - An Evaluation of the Swedish Working Life Fund, John Benjamins Publishing Company, Amsterdam/Philadelphia.

Hall, P. and D. Soskice, (2001), Varieties of Capitalism: The Institutional Foundations of Comparative Advantage, Oxford University Press, Oxford.

Hallgren, E. W. (2009), "How to use an innovation audit as a learning tool: a case study of enhancing high-involvement innovation", Creativity and Innovation Management, Vol. 18.1, pp. 48-58.

Herstad, S. and T. Brekke (2012), "Globalization, modes of innovation and regional knowledge diffusion infrastructures”, European Planning Studies, Vol. 20.10, pp. 1603-1625.

Holm, J. R., E. Lorenz, B. Å. Lundvall and A. Valeyre (2010), "Organizational learning and systems of labor market regulation in Europe", Industrial and Corporate Change, Vol. 19.4, pp. 1141-1173.

Ichniowski, C., K. Shaw and G. Prennushi (1997), "The effects of human resource management practices on productivity: a study of steel finishing lines", American Economic Review, Vol. 87, pp. 291-33.

Jensen, M. B., B. Johnson, E. Lorenz. And B. Å. Lundvall (2007), "Forms of knowledge and modes of innovation", Research Policy, Vol. 36.5, pp. 680-693.

Kalmi, P. and A. Kauhanen (2008), "Workplace innovations and employee outcomes: evidence from Finland", Industrial Relations: A Journal of Economy and Society, Vol. 47.3, pp. 430-459.

Lam, A. (2000), "Tacit knowledge, organizational learning and societal institutions: an integrated framework", Organization Studies, Vol. 21.3, pp. 487-513.

Levine, D. I. and L. D. A. Tyson (1990), "Participation, Productivity, and the Firm's Environment", California Management Review, Vol. 32.4, pp. 86-100.

Lorenz, E. (2004), "Developing Indicators for Skills and Innovation”, Report, European Trend Chart Project, Directorate General Enterprise and Industry, European Commission, Brussels.

Lorenz, E. (2013), "Innovation, work organisation, and systems of social protection", in J. Fagerberg, B. Martin and E. S. Andersen (eds.) Innovation Studies: Evolution and Future Challenge, Oxford University Press, Oxford.

Lorenz, E., F. Wilkinson and J. Michie (2004), "HRM Complementarities and Innovative Performance in French and British Industry", in J. L. Christensen and B.-Å. Lundvall (eds.), Product Innovation, Interactive Learning and Economic Performance, Elsevier Ltd, Amsterdam.

Lorenz, E. and A. Valeyre (2005), "Organisational innovation, human resource management and labour market structure: a comparison of the EU-15”, Journal of Industrial Relations, Vol. 47.4, pp. 424442 .

Meadow Consortium (2010), "The Meadow Guidelines", Project funded within the 6th Framework Programme of the European Commission's DG Research, Grigny, France. 
Mintzberg, H. (1979), The structuring of organizations: A synthesis of the research, University of Illinois at Urbana-Champaign's Academy for Entrepreneurial Leadership Historical Research Reference in Entrepreneurship.

Mintzberg, H. (1983), "Structure in Fives: Designing Effective Organisations", Englewood-Cliffs, NJ: Prentice Hall.

OECD (2018), Leveraging Business Development Services for SME Productivity Growth, OECD Centre for Entrepreneurship, SMEs, Regions and Cities, Paris.

OECD (2015) The Innovation Imperative: Contributing to Productivity, Growth and Well Being, OECD Publishing, Paris.

OECD (2010) Innovative Workplaces: Making Better Use of Skills Within Organizations, OECD Publishing, Paris.

Osterman, P. (2000), "Work reorganization in an era of restructuring: trends in diffusion and effects on employee welfare", Industrial and Labor Relations Review, Vol. 53.2, pp. 179-196.

Osterman, P. (1994), "How common is workplace transformation and who adopts it?", Industrial and Labour Relations Review, Vol. 47.2, pp. 173-188.

Ramsay, H., D. Scholarios and B. Harley (2000), "Employees and high-performance work systems: testing inside the black box", British Journal of Industrial Relations, Vol. 38.4, pp. 501-531.

Ramstad, E. (2005), "Self-Assessment Results of the TYKE Programme's Development Projects (19962003) in Examination", TYKES Reports 47, Ministry of Labour, Helsinki.

Ramstad E. (2008), “Innovation Generating Model - Simultaneous Development of Work Organization and Knowledge Infrastructure." TYKES Reports 65. Ministry of Labour, Helsinki.

Ramstad, E. (2009) "Developmental evaluation framework for innovation and learning networks: integration of the structure, process and outcomes", Journal of Workplace Learning, 21 (3), 181-197.

Ramstad, E. (2014) "Can high involvement innovation practices improve productivity and the quality of working life simultaneously? Management and employee views on comparison", Nordic Journal of Working Life Studies, Vol. 4.4, 25-45

Rissanen, P., Pitkänen, S. and Arnkil, R. (2003) "Just on time: main findings of assessment of the effects of the Finnish Workplace Development Programme effects". Working Papers of the Finnish Workplace Development Programme 14. Helsinki: Ministry of Labour.

Tykes (2011) Työelämän kehittämisohjelman (Tykes) johtoryhymän Ioppuraportti työ-, koulutus- ja elinkeinoasiainneuvostolle, työ-, koulutus- ja elinkeinoasiainneuvostoll, Helsinki.

VINNOVA (2010) Vinnande tjänstearbete - Tio forsknings- \& utvecklingsprojekt om ledning och organisering av tjänsteverksamhet, VINNOVA Information VI 2010:08, Vinnova, Stockholm

VINNOVA (2009), "Research on Managerial Tasks: Conditions, Ways of Working and Results: Presentation of the Projects", VINNOVA Information VI 2009.03, VINNOVA, Sweden. 


\section{Annex A. CORE SURVEY QUESTIONS ANALYSED}

\section{Third European Company Survey 2013 - survey questions used for constructing organisational design indicators}

A team is a group of people working together with a shared responsibility for the execution of allocated tasks, within or across units of the establishment. Do you have any teams fitting this definition in your establishment?

If you think about the tasks to be performed by the teams: Do the team members decide among themselves by whom the tasks are to be performed, or is there usually a superior distributing the tasks within the team?

Do any of the employees at this establishment rotate tasks with other employees?

Do employees in this establishment document and keep records of their good work practices or lessons learned, with the purpose to share these with other employees?

Does this establishment monitor the quality of its production processes or service delivery?

In this establishment, which of the following practices are used to involve employees in how work is organised?

- Suggestion schemes (the collection of ideas and suggestions from the employees, voluntary and at any time, traditionally by means of a 'suggestion box')

- Regular staff meetings open to all employees at the establishment

- Regular meetings between employees and immediate manager

Over the past 12 months, what percentage of employees has received on the job training?

Could you please tell me for each of these options, whether or not they are available to at least some employees? 1) Variable extra pay linked to the individual following management appraisal 2) Variable extra pay linked to the performance of the team, working group or department following management appraisal

Approximately what percentage of the employees has a performance appraisal or evaluation interview at least once a year?

Source: Master English language questionnaire for 3rd ECS 
The Programme for International Assessment of Adult Competencies (PIAAC) Survey survey questions used for constructing work organisation indicators

Can you choose or change the sequence of your tasks to a high or very high extent?

Can you choose or change the way you do your work to a high or very high extent?

Does your job usually involve planning your activities every day?

Does your job involve at least once a week learning-by-doing from the tasks you perform?

Think of "problem solving" as what happens when you are faced with a new or difficult situation which requires you to think for a while about what to do next. Are you usually faced at least once a week by relatively simple problems that takk no more than 5 minutes to find a good solution?

Are you usually confronted at least once a week with more complex problems that take at least 30 minutes to find a good solution? The 30 minutes only refers to the time needed to THINK of a solution, not the time needed to carry it out.

Does your job usually involve at least once a week sharing work-related information with co-workers? workers?

In your job do you usually spend more than half of the time cooperating or collaborating with co-

Source: OECD Programme for International Assessment of Adult Competencies Survey.

http://www.oecd.org/site/piaac/publicdataandanalysis.htm 